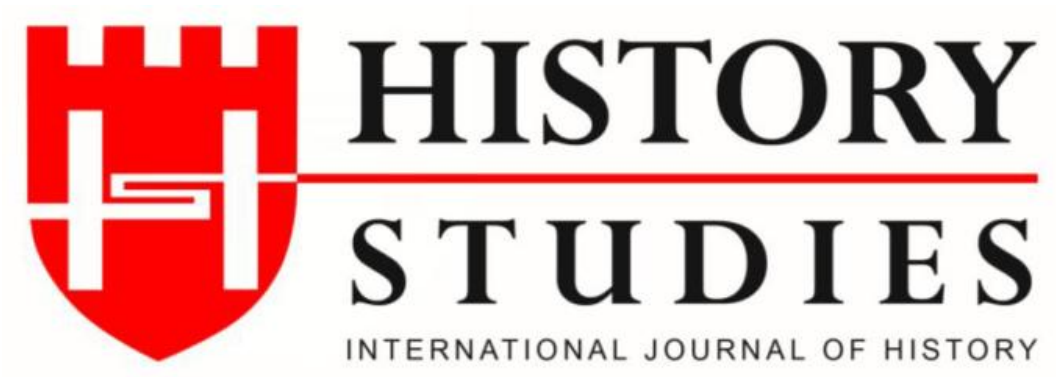

ISSN: 13094173 (Online) 1309 - 4688 (Print)

Volume 12 Issue 6, December 2020

DOI Number: 10.9737/hist.2020.964

Araştırma Makalesi

Makalenin Geliş Tarihi: 11.09.2020 Kabul Tarihi: 22.10.2020

Atıf Künyesi: Esra Türe, “Avrupa Konseyi-Türkiye İlişkilerinin Türk Basınında Yansımaları (19801984)", History Studies, 12/6, Aralık 2020, s. 3245-3268.

\title{
Avrupa Konseyi-Türkiye İlişkilerinin Türk Basınında Yansımaları (1980-1984)
}

Reflections of The Council of Europe-Turkey Relations in The Turkish Press (1980-1984)

\author{
Dr. Esra Türe \\ ORCID No: 0000-0001-9875-0587 \\ Ondokuz Mayıs Üniversitesi
}

Volume 12 Issue 6

Öz

12 Eylül Askeri Darbesi Türkiye'nin iç siyasetinde olduğu kadar dış siyasetinde de değişimlere neden olmuştur. Özellikle Avrupa ülkeleri ve Avrupa kuruluşları Türkiye'deki gelişmeleri yakından takip etmiştir. Avrupa kuruluşları arasında yer alan ve çalışmamızın da konusunu oluşturan Avrupa Konseyi bu süreçte Türkiye'deki demokrasi ve insan hakları konularının özellikle üzerinde durmuştur. Zira Avrupa Konseyi'nin temel yapı taşları olan demokrasi ve insan hakları Türkiye'de ihlal edilmişti. İki temel prensibin ihlali Türkiye ile Avrupa Konseyi’ni sık sık karşı karşıya getirmiştir. Demokratik parlamenter sistemi tekrar tesis etmeyi hedefleyen askeri yönetim, Avrupa Konseyi ile de ilişkilerini devam ettirmeye çalışmıştır. Bu süreç Türk basını tarafından da ilgiyle takip edilmiş ve değerlendirmelere tabi tutulmuştur. Çalışmamızda 12 Eylül Askeri Darbesi’nden sonra tekrar sivil iktidar kurulana kadar geçen sürede Avrupa Konseyi ile Türkiye arasındaki ilişkilerin Türk basınına yansımaları ele alınmıştır. Çalışmamız için dönemin tirajı en yüksek altı gazetesi arasında yer alan Cumhuriyet, Hürriyet, Tercüman ve Milliyet gazeteleri incelenmiş ve kullanılmıştır.

Anahtar kelimeler: Avrupa Konseyi, 12 Eylül darbesi, demokrasi.

\begin{abstract}
September 12 military coup has led to changes in Turkey's foreign policy as well as domestic politics. In particular, European countries and European institutions has closely followed developments in Turkey. The Council of Europe that be one of the among the European institutions and the subject of our study, in this process particularly has focused on democracy and human rights issues in Turkey. Because democracy and human rights that the Council of Europe's fundamental building blocks had been violated in Turkey. Violation of two fundamental principles, has brought confrontations the Council of Europe and Turkey very often. The military administration, aiming to re-establish the democratic parliamentary system, tried to maintain its relations with the Council of Europe, too. This process has been closely followed by the Turkish press and has been evaluationed. In our study has examined that reflections of relations between the Council of Europe
\end{abstract}


and Turkey on the Turkish press from the September 12 military coup until civilian rule was established again. For our study, Cumhuriyet, Hürriyet, Tercüman and Milliyet newspapers, which were among the six most circulated newspapers of the period, were analyzed and used.

Keywords: Council of Europe, September 12 coup, democracy.

\section{Giriş}

İkinci Dünya Savaşı'nın sonlarından itibaren Türkiye'nin izlediği dış politika, iç politikayı da paralel bir şekilde etkilemiştir. Türkiye savaş süresince tarafsız bir tutum sergileyerek denge politikası izleme çalışmıştır. Sovyet Rusya ise bu süreçte Türkiye'ye saldırı olması durumunda Türkiye'nin yanında olacağını bildirmiştir. 22 Haziran 1941 tarihinde Almanya'nın Sovyet Rusya'ya saldırması üzerine Sovyet Rusya, Türkiye'nin de Almanya'ya karşı savaşa girmesini istemiştir. Ancak Türkiye 18 Haziran 1941 tarihinde Almanya ile dostluk Paktı imzalamıştı. ${ }^{1}$ Savaşın sonlarına doğru ise 23 Şubat 1945 tarihinde Mihver Devletlere savaş ilan etmiştir. Çünkü 1945 yılının Nisan ayı sonunda San Fransisco'da yapılacak Birleşmiş Milletler konferansına kurucu üye olarak davet edilebilmek için 1 Mart 1945 tarihinden itibaren Almanya ve Japonya ile savaş halinde olmak gerekliydi. Savaş henüz fiili olarak sona ermeden Sovyet Rusya Türkiye ile 1925'te imzaladıkları Türk-Sovyet Dostluk ve Saldırmazlık Antlaşmasını tek taraflı olarak feshetmiştir. Bununla birlikte Türkiye'den Kars ve Ardahan'1 istemiş, Boğazlar üzerinde üs talep etmiş, fakat Cumhurbaşkanı İsmet İnönü bu talepleri reddetmiştir. ${ }^{2}$ Bunun üzerine Sovyet Rusya Türkiye'ye yönelik ağır bir siyasal baskı uygulamaya başlamıştır. ${ }^{3} \mathrm{Bu}$ süreçte Türkiye konferansa davet edilmiş, ancak Batılı müttefikler ile sıcak ilişkiler kuramamış ve Türkiye dış politikada yalnız kalmıştır. Bu yalnızlık ise Truman Doktrini ile son bulmuştur. ${ }^{4}$ Sovyet Rusya özelikle İkinci Dünya Savaşı'ndan sonra Avrupa, Ortadoğu, Uzakdoğu ve Asya'da komünizmi yayma faaliyetlerine başlamıştır. ${ }^{5}$ Sovyet Rusya'nın yayılmacı bir politika izlemesi ABD'yi endişelendirmiş ve ABD, Sovyet Rusya'ya karşı harekete geçmiştir. ABD'nin ilk eylemi 1947'de Truman Doktrini' ni ${ }^{6}$ hazırlamak olmuştur. Böylece Yunanistan ve Türkiye'ye mali yardım yapılmıştır. Truman Doktrini'nin uygulanması sonucunda dünya iki bloğa ayrılmış ve Sovyet Rusya-ABD mücadelesini kapsayan "Soğuk Savaş" dönemi başlamıştır.

\footnotetext{
1 Zehra Aslan, “Türk-Rus İlişkileri Ekseninde Türkiye'de İktidarların 'Sol’ Algısı (1923-1960)”, Karadeniz Araştırmalarl, S. 51, Güz 2016, s. 178.

${ }^{2}$ Mustafa Aydın, "1939-1945: Savaş Kaosunda Türkiye, Göreli Özerklik-2”, Türk Dış Politikası, Ed. Baskın Oran, C. I, 15. Basım, İletişim Yayınları, İstanbul 2009, ss. 472-474.

${ }^{3}$ Mehmet Gönlübol-Haluk Ülman, "İkinci Dünya Savaşından Sonra Türk Dış Politikası (1945-1965):Genel Durum", Olaylarla Türk Dış Politikası (1919-1995), 9. Basım, Siyasal Kitabevi, Ankara 1996, s. 193.

${ }^{4}$ Cemil Koçak, Türkiye’de Milli Şef Dönemi (1938-1845), C. 2, 7. Basım, İletişim Yayınları, İstanbul 2017, ss. 547, 548.

${ }^{5}$ Fahir Armaoğlu, 20. Yüzyll Siyasi Tarihi (1914-1995), 23. Basım, Timaş Yayınları, İstanbul 2017, s. 379.

6 Özellikle İkinci Dünya Savaşı'ndan sonra Sovyet Rusya'nın neredeyse tüm dünyada etkin olarak komünizmi yayma faaliyetleri Batı ülkelerini oldukça tedirgin etmiştir. Bu dönemde Yunanistan'da yaşanan iç savaş nedeniyle komünizm tehdit unsuru haline gelmiştir. İngiltere İkinci Dünya Savaşı'ndan itibaren Yunanistan ve Türkiye'ye yaptığı askerleri yardımlara devam edememiş ve ABD'ye 21 Şubat 1947 tarihinde bir muhtıra vererek Batı'nın güveliği için Yunanistan ve Türkiye’nin bağımsızlığının önemini vurgulayarak bu ülkelere siyasi ve ekonomik yardımların devam ettirilmesi gerektiğini belirtmiştir. ABD Başkanı Truman, Sovyet Rusya'nın ve komünizmin yayılmasını engellemek amacıyla, düzenlediği kongrede 12 Mart 1947 tarihinde hükümetten Türkiye ve Yunanistan'a askeri yardım yapılması için yetki verilmesini istemiştir. 22 Mayıs 1947' de yürürlüğe giren "Yunanistan ve Türkiye'ye Yardım Kanunu”nun ardından 12 Temmuz 1947'de imzalanan Türk-Amerikan antlaşmasıyla Türkiye’ye askeri yardımlar başlamıştır. Bkz. Yusuf Sarınay, “Türkiye’nin NATO’ya Girişi”, Türkler Ansiklopedisi, C. 16, Yeni Türkiye Yayınları, Ankara 2002, s. 1710.

${ }^{7}$ Rifat Uçarol, Siyasi Tarih (1789-2014), 10. Basım, Der Yayınları, İstanbul 2015, ss. 939-942.
} 
Batı Avrupa devletleri, artan Sovyetler Birliği tehdidine karşı ve uluslararası arenada kaybettikleri eski önemlerini yeniden kazanabilmek için İkinci Dünya Savaşı'ndan sonra İngiltere, Fransa, Belçika, Hollanda, Lüksemburg, Danimarka, İrlanda, İtalya, Norveç ve İsveç 5 Mayıs 1949 tarihinde Londra'da bir antlaşma imzalayarak Avrupa Konseyi'ni kurmuşlardır. ${ }^{8}$ Konseyin amacı Avrupa'da iki savaş arası dönemde görülen özellikle diktatörlük, insan hakları ihlalleri ve soykırımlara karşı demokrasiyi, liberalizmi ve insan haklarını savunan bir topluluk kurmaktır. ${ }^{9}$ Avrupa Konseyi, Bakanlar Komitesi ve Danışma Meclisi (Parlamenter Meclisi) olmak üzere iki organdan teşekkül edilmiş ve Konsey'de iki organa hizmet veren Sekreterlik yer almıştır. Konsey merkezi Strasbourg'dur. Avrupa Konseyi'nin görüşme organı olan Danışma Meclisi'nde alınan kararlar tavsiye niteliği taşımakla birlikte Bakanlar Komitesi'ne sunulmaktadır. Üye ülkelerin Dışş̧leri Bakanlarından oluşan Bakanlar Komitesi ise Konsey'de varılan kararların uygulamaya geçtiği organdır. ${ }^{10}$ Türkiye'nin Konsey'e alınmaması Türkiye'de tepkilere neden olmuş ve üzüntüyle karşılanmıştır. Ancak bu durum uzun sürmemiş Avrupa Konseyi Bakanlar Komitesi'nin 8 Ağustos 1949 tarihinde Strasbourg'da yapılan toplantısında Türkiye, Yunanistan ve İzlanda'nın Konsey'e davet edilmesine karar verilmiştir. ${ }^{11}$ Türkiye, Türkiye Büyük Millet Meclisi'nde (TBMM) 12 Aralık 1949 tarihinde kabul edilen ve 17 Aralık'ta yayınlanan kanun ile Konsey'e katılmayı onaylamış ve Türkiye 8 Ağustos 1949 tarihinden itibaren Avrupa Konseyi üyesi olmuştur. ${ }^{12}$ Bu dönemde TBMM'de Cumhuriyet Halk Partisi ve Demokrat Parti milletvekilleri ile beş bağımsız milletvekili yer almaktaydı. Muhalefet partisi Demokrat Parti adına konuşan Manisa Milletvekili Yunus Muammer Alakant, hükümetin Konsey üyeliği kararını desteklediklerini belirtmiştir. ${ }^{13}$ Türkiye, Konsey’e katılımı Avrupa ulusuna katılacağının bir işareti olarak gördüğü için memnuniyetle karşılamıştır. Zira bu dönemde Cumhurbaşkanı İsmet İnönü’nün de belirttiği gibi "medeni dünyanın saygıdeğer bir üyesi” olarak kabul edilmek Türkiye için önemliydi. ${ }^{14} \mathrm{Bu}$ bir anlamda Türkiye için Avrupalı olma isteğinin Avrupalılar tarafından onaylandığının bir göstergesi olarak değerlendirilmiştir. ${ }^{15}$

Volume 12 Issue 6

December 2020

\section{Avrupa Konseyi’nin 12 Eylül Darbesine Yaklaşımı ve Yaklaşımların Değerlendirilmesi}

12 Eylül 1980 tarihinde Genelkurmay Başkanı Orgeneral Kenan Evren komutasındaki Türk Silahlı Kuvvetleri (TSK) askeri bir darbe gerçekleştirmiştir. Parlamento ve hükümet feshedilmiş, her türlü siyasal, toplumsal ve kültürel faaliyetler yasaklanmış, siyasi partiler kapatılmıştır. 12 Eylül 1980 tarihinde Kenan Evren başkanlığında oluşturulan ve yönetimi ele alan Milli Güvenlik Konseyi'nin (MGK) 1 Numaralı Bildirisine göre, "Türkiye Cumhuriyeti'nin, dış ve iç düşmanların tahriki ile varlığına, rejimine ve bağımsızlığına yönelik fikri ve fiziki haince saldırılar içinde" olduğu gerekçesiyle "Türk Silahlı Kuvvetleri, iç hizmet kanunun verdiği Türkiye Cumhuriyeti'ni kollama ve koruma görevini yüce Türk Milleti adına emir komuta zinciri içinde ve emirle yerine getirme kararını almış ve ülke yönetimine bütünüyle el koymuştur." 16

\footnotetext{
${ }^{8}$ age, ss. $1020,1021$.

${ }^{9}$ Ali Servet Öncü-Erkan Cevizliler, “Avrupa Bütünleşmesi İçin Önemli Bir Adım: ‘Avrupa Konseyi’ ve Türkiye’nin Konseye Üyeliği Meselesi, Akademik Bakış, 7/13, 2013, s. 23.

10 “Avrupa Konseyi Statüsü”, Ankara Barosu Dergisi, Y11: 75, 2017/3, ss. 584-588.

${ }^{11}$ Gönlübol-Ülman, age, s. 226.

12 “Avrupa Konseyi’nin kurulması hakkında imzalanmış olan Statü’nün onanmasına dair Kanun”, T.C. Resmi Gazete, 17 Aralık 1949, s. 17380.

13 TBMM Tutanak Dergisi, C. 22, On altıncı Birleşim, 12.XII.1949, s. 181.

${ }^{14}$ William Hale, Türk Dış Politikası 1774-2000, Çev. Petek Demir, Mozaik Yayınları, İstanbul 2003, s. 117.

15 İhsan Duran Dağı, "Democratic Transition in Turkey, 1980-83: The Impact of European Diplomacy", Middle Eastern Studies, 32/2, 1996, pg. 131.

16 “Milli Güvenlik Konseyi'nin 1 Numaralı Bildirisi”, T.C. Resmi Gazete, 12 Eylül 1980, s. 6.
} 
Evren 12 Eylül günü yaptığı açıklamada demokratik parlamenter düzene en kısa zamanda geçileceğini vurgulamış ve NATO dahil tüm ittifak ve anlaşmalara bağlı kalarak ilişkilerin sürdürüleceğini belirtmiştir. ${ }^{17}$ Avrupa Konseyi Parlamenter Meclisi (AKPM) Başkanı Hans J. De Coster 12 Eylül sabahı yayınladığı basın bildirisinde Türkiye'deki darbeye ilişkin görüşlerinin olumsuz olduğunu ifade etmiştir. De Coster TSK'nın yönetime el koyduğu haberinin endişeyle karşılandığı belirtilerek Türkiye'nin demokratik Avrupa ülkeleri arasında yer almasına önem verdiklerini vurgulamıştır. $\mathrm{Bu}$ nedenle de yeni askeri yönetimden demokrasiye dönüş konusundaki kararlılıklarını kanıtlamalarını istemiş ve seçimlere ilişkin bir tarih bekleneceğini belirtmiştir. De Coster ayrıca 24 Eylül-2 Ekim 1980 tarihleri arasında yapılacak AKPM oturumuna katılmasını istedikleri TBMM heyetinin tutuklanmaması için çağrıda bulunmuştur. ${ }^{18}$

AKPM'nin Strasbourg'da yapılacak olan 24 Eylül-2 Ekim 1980 tarihleri arasındaki toplantısına MGK, AKPM'nin tutuklanmayan Türk üyeleri arasında olan Turan Güneş, Metin Toker, Besim Üstünel ve Cevdet Akçalı'nın katılmalarına izin vermiştir. ${ }^{19} 12$ Eylül'den sonra Strasbourg'a gidecek olan Türk üyeler Milliyet gazetesinde, Türkiye'nin yeni rejimi ve demokrasiye dönüşü konusunda dışarıya karşı ilk sınavını verecek isimler olarak nitelendirilmişlerdir. ${ }^{20}$ AKPM'de Türkiye'deki durum ve TSK'nın yönetime el koyması konusu görüşülerek Avusturyalı parlamenter Ludwig Steiner'ın hazırladığı tasarı kabul edilmiştir. Alınan tavsiye kararında oturuma katılan Türk üyelerin görev sürelerinin 11 Mayıs 1981 tarihine kadar geçerli olduğu, bu tarihe kadar Türkiye'de seçimler yapılmadığı takdirde Türk üyelerin AKPM'ye katılmalarının sonlandırılacağı yer almıştır. ${ }^{21}$ Genel itibariyle ise Avrupa Konseyi Türkiye'de parlamentonun feshinin, siyasi parti faaliyetlerinin yasaklanmasının ve çeşitli konularda getirilen kısıtlamaların Avrupa Konseyi Statüsü ile bağdaşmadığını vurgulamıştır. 904 sayılı kararla Bakanlar Komitesi'ne tavsiyede bulunarak Türkiye'deki durumun yakından izlenmesi istenmiştir. ${ }^{22}$

AKPM'nin Eylül ayındaki toplantısının ardından alınan tavsiye kararlarını değerlendiren Avrupa Konseyi Bakanlar Komitesi 16 Ekim 1980 tarihinde Strasbourg'da toplanmış ve Türkiye konusunu görüşmüştür. AKPM'ye üye ülkelerin dışişleri bakanlarının katıldığı Bakanlar Komitesi toplantısına katılmak üzere Dıșişleri Bakanı İlter Türkmen 16 Ekim 1980 tarihinde Strasbourg'a gitmiştir. ${ }^{23}$ Türk vatandaşlara vize uygulaması getiren Almanya, Fransa ve İsviçre'ye ek olarak Benelüks ülkeleri (Belçika, Hollanda, Lüksemburg) de Türklere 1 Aralık 1980 tarihinden itibaren vize uygulayacaklarını açıklamışlardır. Kendisine de vize sorunu yaşatılan Türkmen, Avrupa Konseyi üyesi 20 ülkenin dışişleri bakanlarına vize konusunda sert uyarılarda bulunarak vizenin kaldırılmasını istemiş ve vize kararının Batı Avrupa ülkeleri ile olan ilişkilerini gölgelediğini belirtmiştir. Almanya dışişleri bakanı ise vize uygulamasıyla "sahte siyasi iltica" hareketlerinin durdurulmasının amaçlandığını, uygulamanın geçici olduğunu ve Türkiye'deki gelişmelere bağlı olarak kaldırılabileceğini ifade etmiştir. Fransa dışişleri bakanı ise uygulamanın ekonomik nedenlerle alındığını ve Türk-Fransız dostluğunu etkilememesi

\footnotetext{
17 "Genelkurmay ve Milli Güvenlik Konseyi Başkanı Orgeneral Kenan Evren'in Türk Milletine Açılaması”, T.C. Resmi Gazete, 12 Eylül 1980, s. 4.

${ }^{18}$ Kaan Esener, Avrupa Konseyi ve Türkiye, (Ankara Üniversitesi Sosyal Bilimler Enstitüsü Yayımlanmamış Yüksek Lisans Tezi), Ankara 2003, ss. 15, 16.

${ }^{19}$ Kenan Evren, Kenan Evren 'in Anıları, C. 2, Milliyet Yayınları, İstanbul 1991, s. 90.

20 ““12 Eylül'ün Dış Dünyadaki İlk Sınavı”, Milliyet, 16 Eylül 1980, s. 1.

21 “Avrupa Konseyi, Türkiye'de Demokrasiye Dönüş Sürecini İzleyecek”, Milliyet, 2 Ekim 1980, s. 7.

${ }^{22}$ Council of Europe-Parliamentary Assembly, Situation in Turkey, Recommendation 904, http://semanticpace.net/tools/pdf.aspx?doc=aHR0cDovL2Fzc2VtYmx5LmNvZS5pbnQvbncveG1sL1hSZWYvWDJILURXLWV4 dHIuYXNwP2ZpbGVpZD0xNDkzOCZsYW5nPUVO\&xsl=aHR0cDovL3NlbWFudGljcGFjZS5uZXQvWHNsdC9 QZGYvWFJIZi1XRC1BVC1YTUwyUERGLnhzbA==\&xsltparams=ZmlsZWlkPTE0OTM4 (05.04.2020).

23 “Türkmen Avrupa Konseyi'nde Demokrasiye Dönüș İçin Güvence Verdi”, Cumhuriyet, 17 Ekim 1980, ss. 1, 7.
} 
gerektiğini belirtmiştir. Türkmen, Bakanlar Komitesi'nde yaptığı konuşmada askerlerin sivil yönetime geçme konusunda kararlığını ortaya koymaya çalışmış, ancak demokrasiye geçiş süresi hakkında bilgi vermemiştir. ${ }^{24}$

Bakanlar Komitesi toplantısından sonra yayınlanacak olan bildirinin Türkiye ile ilgili kısmına İsveç dışişleri bakanı, kararların yumuşak olduğu gerekçesiyle itiraz etmiş ve Türkiye'nin demokrasiye dönüş konusunda tarih vermesi gerektiğini vurgulamıştır. Türkmen ise bildirinin geldiği şekliyle yayınlanmasını istemiştir. Toplantıda başta Yunanistan olmak üzere Portekiz, Kıbrıs Rum kesimi ve Norveç de İsveç’i desteklemişlerdir. Ancak bildiri Türkiye'nin istediği şekliyle kabul edilmiştir. Bildirinin Türkiye ile ilgili bölümü şu şekildedir: ${ }^{25}$

Türk Dışişleri Bakanı Türkmen hükümetinin en kısa sürede demokrasiye geri dönülmesi ve bu geçiş döneminde insan haklarına yasalara ve temel hürriyetlere bağlı kalma konusundaki kararlılığını belirtmiştir. Türkmen, hükümetinin Avrupa Konseyi ile tüm alanlarda işbirliğini sürdürmeye verdiği önemi tekrarlamıştır. Öteki bakanlar, parlamenter demokrasiye, yasalara saygıya ve temel hürriyetler ilkesine saygı gösterilmesine verdikleri önemi vurgulamışladır.

Türkiye ile Avrupa ilişkilerini ele alan Milliyet gazetesi, Türkiye'nin yaşayacağı en önemli sorunun demokrasiye dönüş konusunda Avrupa Konseyi'ni "inandırma" noktasında oluşacağına dikkat çekmiştir. Gazete, Türkiye'ye 31 Ocak 1981 tarihine kadar süre tanıyan Avrupa Konseyi'nin bu kararını da "inandırıcılık konusundaki kararını erteleme" olarak değerlendirmiştir. ${ }^{26}$ Milliyet gazetesi yazarlarından Mümtaz Soysal, demokrasiye dönüş konusundaki zamanlamanın dış ülkeler istediği için değil, Türkiye'yi yanlışlardan korumak gayesiyle yapılması gerektiğini belirtmiştir. Zira yazar, 12 Eylül öncesinde dış ülkelerin Türkiye'yi parçalamak için bir iç savaşın eşiğine getirdiğine dikkat çekmiş ve demokrasiye dönüşte dış akılların değil, Türkiye yönetimin kendi aklını kullanması gerektiğine vurgu yapmıştır. ${ }^{27}$ Ayrıca bu dönemde İran'da yaşanan rejim sorunu, petrol bölgelerinin güvenliği ve Ortadoğu ülkelerindeki anlaşmazlıklar başta olmak üzere birçok olay Türkiye'nin Batı için vazgeçilmez olduğu kanaatini doğurmuştur. ${ }^{28}$

Aralık ayında Brüksel'de temaslarda bulunan Türkmen, 18 Aralık 1980 tarihinde düzenlediği basın toplantısında Batı'ya takvim vermediğini, ancak Kurucu Meclis'in teşekkül edecek olmasını demokrasiye dönüşün ilk adımı olarak sunmuştur. ${ }^{29}$ Kurucu Meclis, bu dönemde demokrasiye dönme konusunda somut bir örnek olarak değerlendirilmiştir. ${ }^{30}$ Ancak Türk basınında Batı'nın Türkiye'ye yönelik demokrasi yaklaşımına ilginç değerlendirmeler yapılmıştır. Mümtaz Soysal, Türkiye'nin demokrasiye geçip geçmemesinin dış ülkeler için bir önem taşımadığını savunmuştur. Hatta Avrupa Konseyi'nin dışına itilerek Ortadoğu bekçisi konumuna getirilen ve otoriter rejimlerle yönetilen bir Türkiye'nin Batı tarafindan daha çok arzu edilebileceğini belirtmiştir. ${ }^{31}$ Cumhuriyet gazetesi yazarı İlhan Selçuk da aynı görüşü savunarak parlamenter rejim görünümü altında fikir özgürlügüne sahip olamayan bir Türkiye'nin Batı tarafından kendi çıkarlarına daha uygun görüleceğini ifade etmiştir. ${ }^{32}$

\footnotetext{
${ }^{24}$ Council of Europe, Minutes of The 67th Session of The Committeeof Ninisters, 16 October 1980, https://rm.coe.int/native/09000016804d64d3, pg. 25-27, 42, (10.09.2020).

25 Council of Europe, Minutes of The 67th Session of The Committeeof Ninisters, 16 October 1980, https://rm.coe.int/native/09000016804d64d3, pg. 52-57, (10.09.2020).

26 "Kamuoyu Desteği”, Milliyet, 17 Ekim 1981, s. 1.

${ }^{27}$ Mümtaz Soysal, “Ak1l Takvimi”, Milliyet, 5 Kasim 1980, s. 2.

28 “Türkiye'nin Önemi”, Milliyet, 19 Kasım 1980, s. 1.

29 “Türkmen: 'Kimseye Demokrasiye Geçiş Takvimi Vermedim”, Tercüman, 19 Aralık 1980, ss. 1, 12.

${ }^{30}$ Cüneyt Arcayürek, "Demokrasiye Geçiş Tartışmaları", Hürriyet, 21 Aralık 1980, s. 6.

${ }^{31}$ Mümtaz Soysal, "Dış Baskı", Milliyet, 20 Aralık 1980, s. 2.

32 İlhan Selçuk, "Bağımsız Türkiye'de Demokrasiye Doğru...", Cumhuriyet, 22 Aralık 1980, s. 2.
} 


\section{Avrupa Konseyi'nin Türkiye'deki Demokrasi Gelişmelerini Takibi ve Türk Parlamenterlerin Konsey'de Temsili Sorunu}

12 Eylül sonrasında demokrasiye dönüș konusunda bazı çevrelerin dıș baskı unsurunu kullanarak kampanya yürüttüklerini belirten Kenan Evren, demokrasiye dönüşün dış baskılarla değil, milletin kararıyla gerçekleşeceğini vurgulamıştır. ${ }^{33}$ Evren'in açıklamasından sonra basında "Dış baskı mı var?" sorusu gündeme gelmiştir. Evren'in açıklık getirmediği bu konuyu tartışan basın, Batı'dan gelen baskının şimdilik Avrupa Konseyi tarafından yapıldığını ortaya koymuştur. ${ }^{34}$ Prof. Dr. İhsan Duran Dağı da Konsey'in her toplantı döneminden önce Türkiye'ye raportörler göndermesini Türkiye'ye sürekli olarak baskı yapmanın araçlarından biri olarak değerlendirmiştir. ${ }^{35} \mathrm{Bu}$ kapsamda Avrupa Konseyi tarafından Türkiye'deki gelişmeleri izlemesi ve 26 Ocak'ta başlayacak olan Konsey toplantılarına sunmak üzere rapor hazırlaması için tekrar görevlendirilen Steiner, 6 Ocak 1981 tarihinde Anakara' daki temaslarına başlamıştır. ${ }^{36}$ Milliyet gazetesi Steiner'ın hazırlayacağı raporu, "12 Eylül iktidarının dış dünyada geçireceği en önemli siyasal sınavın temel değerlendirme belgesi" olarak nitelendirmiştir. ${ }^{37}$ Steiner, yaptığ görüşmeler sonucunda TSK'dan demokrasiye dönme konusunda olumlu izlenimler edindiğini açıklamıştır. Steiner ayrıca Türkiye'nin 12 Eylül'e gelmesinde Batılı ülkelerin de sorumlu olduğunu belirterek Türkiye'de demokrasinin yaşaması için Avrupa'nın üzerine düşen görevi yapmadığını vurgulamış ve Türkiye'nin Avrupa'nın önemli bir unsuru olduğunu ifade etmiştir. ${ }^{38}$ Resmi makamlarla da görüşen Steiner, kimsenin kendisine demokrasiye dönüş konusunda bir takvim belirtmediğini, ancak edindiği izlenime göre Mayıs ayından önce bir takvim verilme ihtimalinin olduğunu söylemiştir. Steiner bu izlenimini yazılı raporuna ekleyemeyeceğini, ancak sözlü olarak aktaracağını ifade etmiştir. Zira Mayıs ayı, AKPM üyelerinin yenileneceği ve Türk parlamenterlerin durumunun da netlik kazanacağı ay olması nedeniyle önem taşımaktaydı. ${ }^{39}$

Steiner'ın temaslarının ardından Evren 15 Ocak 1981'de Kurucu Meclis'in 30 Ağustos ile 29 Ekim 1981 arasında bir tarihte kurulacağını açıklamıştır. ${ }^{40}$ Hürriyet gazetesi yazarı Cüneyt Arcayürek, Evren'in Kurucu Meclis tarihine ilişkin yaptığı açıklamayı beklenmeyen, ani bir gelişme olarak değerlendirmiş ve şaşırdıklarını ifade etmiştir. ${ }^{41}$ Kurucu Meclis tarihinin açılanmasının Avrupa Konseyi'nde Türkiye'ye rahatlık sağlaması beklenmiştir. Demokrasiye dönüşte somut bir adım olarak değerlendirilen Kurucu Meclis tarihi, Türkiye'deki yönetimi destekleyen Avrupa Konseyi üyelerine Türkiye'nin Konsey'den çıkarılmasını isteyen üyeler ile mücadele edebilme olanağı sağladığı aktarılmıştır. ${ }^{42}$

Avrupa Konseyi'nin 26 Ocak’ta başlayan oturumuna Türk delegasyonu olarak 12 eski parlamenter katılmıştır. Bu isimlerin 6'sı eski CHP'li Muammer Aksoy, Hikmet Çetin, Besim Üstünel, Turan Güneş, Abdullah Köseoğlu, Uğur Alacakaptan, 5'i eski AP'li Cevdet Akçalı, Halit Evliya, Şaban Karataş, Kemal Kaçar, Oral Karaosmanoğlu ve Kontenjan eski senatörü Metin Toker'den oluşmuştur. ${ }^{43}$ Konsey'de Türkiye ile ilgili ele alınan en önemli konulardan biri Kurucu Meclis olmuştur. AKPM'de yöneltilen eleştiriler arasında Evren'in Kurucu Meclis'in

\footnotetext{
33 “Demokrasiye Dönüş Tarihini 1981'de Açıklayacağım”, Hürriyet, 19 Aralık 1980, ss. 1, 9.

${ }^{34}$ Cüneyt Arcayürek, "Demokrasiye Geçiş Tartışmaları", Hürriyet, 21 Aralık 1980, s. 6.

${ }^{35}$ Dağl, agm, pg. 132.

36 “Avrupa Konseyi Temsilcisi Steiner, Ankara'daki Temaslarına Başladı”, Cumhuriyet, 7 Ocak 1981, s. 1.

37 “Hepimiz Sinavdayız...", Milliyet, 7 Ocak 1981, s. 1.

38 "Steiner: Avrupa Türkiye’ye Karşı Görev Yapamadı", Hürriyet, 9 Ocak 1981, s. 1.

39 ““Türk Hükümeti, Demokrasiye Dönüş Konusunda Kararlı”, Milliyet, 9 Ocak 1981, s. 7.

40 “"Kurucu Meclis'e Partili Alınmayacak”, Hürriyet, 16 Ocak 1981, ss. 1.

${ }^{41}$ Cüneyt Arcayürek, "Evren'in Ani Gelen Açıklaması”, Hürriyet, 16 Ocak 1981, ss. 1, 13.

${ }^{42}$ Mehmet Ali Birand, "Olumlu Gelişmeler Var", Milliyet, 16 Ocak 1981, s. 7.

43 “Steiner Raporuna, Evren'in Kurucu Meclis Konusundaki Açılaması Eklendi”, Milliyet, 23 Ocak 1981, s. 7.
} 
kurulacağı tarihle ilgili konuşmasının demokrasiye geçişin göstergesi olmadığı yer almış, tam tersine demokrasiden uzaklaşmayı ifade ettiği ileri sürülmüştür. ${ }^{44}$ Evren'in Kurucu Meclis hakkındaki konuşmasının AKPM'de görmezden gelinmesi, Konsey'in tarafsızlığı konusunda Türk kamuoyunda şüphe oluşturmuştur. ${ }^{45}$ AKPM'de son sözü alan Metin Toker, Avrupa Konseyi-Türkiye ilişkileri arasında makul bir uzlaşma oluşturmaya çalışırken, “...Avrupa Konseyi'nin üyesi de kalsak, üyesi kalmasak da Türkiye en kısa süre içinde demokrasisini sağlığa kavuşturacaktır. Ama siz, çiftin arasında anlaşmazlık var diye, geçici de olsa evlerin ayrılmasına karar verirseniz, barışmak istediğinizde bir de bakarsınız, eşinizi başkası alıp götürüvermiş. Türkiye'nin talibinin çok olduğunu bilesiniz." şeklindeki ilginç ifadesiyle dikkatleri çekmiştir. ${ }^{46}$ Cumhuriyet gazetesi yazarlarından Uğur Mumcu, Metin Toker'in bu ifadelerine sert tepki göstererek Türkiye'nin Konsey'de böyle bir benzetme ile temsil edilmesini eleştirmiştir. ${ }^{47}$ Konsey'de 29 Ocak 1981 tarihinde yapılan oylamada Türkiye için hazırlanmış olan rapor ve 395 numaralı direktif kabul edilmiştir. Buna göre sadece demokratik ilkelere saygı duyan ülkelerin Konsey üyeliğini sürdürebileceği hatırlatılarak Türkiye'de şu anda demokratik ilkelerin uygulanmadığı, ancak normal demokratik düzene dönüşün beklendiği belirtilmiştir. Kabul edilen kararda Türkiye'deki iç gelişmelerin yakından takip edilmesi, Mart 1981'de Lahey'de yapılacak toplantıda Türkiye konusunun tekrar gözden geçirilmesi ve Mayıs 1981 oturumunda Türkiye'deki gelişmelerin tekrar inceleneceği yer almıştır. ${ }^{48}$ Çıkan karar üzerine Steiner tekrar Türkiye'ye gelerek yeni bir rapor hazırlayacaktır. Steiner'ın yanı sıra Konsey Başkanı De Coster ve genel sekreter de Türkiye'deki gelişmeler hakkında inceleme yaparak Konsey'e bilgi vereceklerdir. ${ }^{49}$

Steiner'ın hazırladığı ve Konsey tarafından da kabul edilen rapor Türk basınında da tartışılmış̧ır. Tercüman gazetesi yazarlarından Nazlı Ilıcak, Steiner'ın raporuna eleştiri getirerek, raporda 12 Eylül öncesi durum ve 12 Eylül'den sonra hedeflenenler dışında Türkiye'de demokrasinin neden olmadığının da gerekçeleri ile gösterilmesi gerektiğini savunmuştur. Zira Siyasi İşler Komisyonu'nda Steiner'ın raporuna Türkiye'de demokrasinin olmadığına dair açıklamalar eklenmiş ve Türkiye aleyhinde bir hava oluşmuştur. Ilıcak, 12 Eylül'den sonra Türkiye'deki durumun demokratik olmadığının herkes tarafından kabul edildiğini vurgulayarak Avrupa Konseyi'nin bu süreçte 12 Eylül'ün sebepleri ve hedeflenen demokrasi üzerinde durmas1 gerektiğini belirtmiştir. ${ }^{50}$ Cumhuriyet gazetesi yazarlarından Ali Sirmen ise Avrupa Konseyi'nin tutumunun Türkiye'nin içişlerine bir müdahale olarak değerlendirilip değerlendirilemeyeceği konusunu tartışmıştır. Yazar, Konsey'in Türkiye'deki rejim ve insan hakları uygulamaları konusundaki yaklaşımını Türkiye'nin içişlerine müdahale olarak değerlendirmemektedir. Çünkü Türkiye, Avrupa Konseyi'nin koşullarını kabul ederek Konsey'e üye olmuştu ve Konsey'in de Türkiye'deki rejim ve insan hakları uygulamalarına ilgi göstermesi doğaldı. Ancak Sirmen bu ilginin 12 Eylül'den önce gösterilmeyip 12 Eylül'den sonra gösterilmesini bir çelişki olarak değerlendirmiş ve eleştirmiştir. ${ }^{51} 23$ Mart 1981 tarihinde Lahey'de toplantı yapan Avrupa Konseyi Tüzük Komisyonu, Konsey’de kabul edilen 395 sayılı direktif gereğince Türkiye'deki

\footnotetext{
${ }^{44}$ Cüneyt Arcayürek, “Dost Böyle mi Acı Söyler?..”, Hürriyet, 30 Ocak 1981, ss. 1, 13.

${ }^{45}$ Oktay Ekşi, "Ne Siyah Ne de Pembe Gözlük", Hürriyet, 31 Ocak 1981, s. 1.

${ }^{46}$ Metin Toker, "Bizden Olmayan Bizimkiler", Milliyet, 1 Şubat 1981, s. 6.

${ }^{47}$ Uğur Mumcu, "Bu kafa...”, Cumhuriyet, 3 Şubat 1981, ss. 1, 11.

48 Council of Europe-Parliamentary Assembly, Situation in Turkey, Order 395, http://semanticpace.net/tools/pdf.aspx?doc=aHR0cDovL2Fzc2VtYmx5LmNvZS5pbnQvbncveG1sL1hSZWYvWDJILURXLWV4 dHIuYXNwP2ZpbGVpZD0xMzYwMSZsYW5nPUVO\&xsl=aHR0cDovL3NlbWFudGljcGFjZS5uZXQvWHNsdC 9QZGYvWFJIZi1XRC1BVC1YTUwyUERGLnhzbA==\&xsltparams=ZmlsZWlkPTEzNjAx, (05.04.2020).

49 “Avrupa Konseyi, Siyasi Komisyon'un Karar Tasarısını Büyük Çoğunlukla Kabul Etti”, Milliyet, 30 Ocak 1981, s. 6.

${ }^{50}$ Nazlı Ilıcak, “Avrupa Konseyi Kararı”, Tercüman, 31 Ocak 1981, ss. 1, 12.

${ }^{51}$ Ali Sirmen, "İki Karar", Cumhuriyet, 1 Şubat 1981, s. 5.
} 
gelişmeleri tekrar değerlendirmiş ve 7'ye karş1 9 oyla Türk parlamenterlerin Konsey'deki görev sürelerinin uzatılmasının Konsey tüzüğüne aykırı olmadığını kabul etmiştir. ${ }^{52}$ Tüzük Komisyonu'nun aldığı karar aslında tavsiye niteliği taşımaktadır. Ancak yine de bu karar Türk parlamenterler için olumlu bir gelişme olarak görülmüştür. ${ }^{53}$ Konsey'in Türkiye üzerinde özellikle durması Türkiye'nin lehine bir durum olarak düşünülmüsstür. Az bir farkla alınan bu karar Batı'nın Türkiye'yi bir parçası olarak gördüğü ve görmek istediği anlamında yorumlanmıştır. Türkiye ise Batı'nın bu duyarlılığı karşısında Batı'nın bir parçası olmaktan vazgeçmediğini hem kendisine hem de tüm dünyaya ispatlamakla sorumlu tutulmuştur. ${ }^{54}$ Avrupa Konseyi ile Türkiye arasında gerilen ilişkiler bir anlamda Türkiye-Avrupa arasındaki genel ilişkinin bir örneğidir. Bu noktadan bakıldığında Türkiye bu süreçte aynı zamanda Batı'nın bir parçası olduğunu dünyaya kabul ettirme gayreti de göstermiştir. ${ }^{55}$ Nazlı Ilıcak'ın değerlendirmesine göre Batı ile Türkiye ilişkilerinde soğuma yaşanması durumunda Türkiye, ABD ile baş başa bırakılarak Ortadoğu'da Mısır örneğinde olduğu gibi bir modelle karşı karşıya kalabilecektir. ${ }^{56}$

Avrupa Konseyi'nin Ocak ayında aldığı karar doğrultusunda De Coster 12 Nisan 1981 tarihinde Türkiye'ye gelerek incelemelerde bulunmuştur. ${ }^{57}$ De Coster'ın hazırladığı rapor 28 Nisan 1981'de Avrupa Konseyi Siyasi İşler Komisyonu'nda, 29 Nisan'da Başkanlık Divanı'nda görüşülmüştür. 27.04.1981 tarih ve Asbur (32) 52 no ile Siyasi Komite ve Başkanlık Divanı| üyelerine "Basından gizli tutulması" talebiyle dağıtılan De Coster'ın "Türkiye'deki Gelişmeler" başlıklı raporunda öne çıkan hususlar şu şekildedir: Türk kamuoyu ve toplumu, askeri "müdahalenin" gereklilik sonucunda yapıldığı görüşünü taşımakta ve askeri yönetimden memnun görünmektedir. Ordunun demokrasiye dönme isteğinden şüphe duyulmamaktadır. Tutuklulara kötü muamelenin yani işkence sorununun tarihinin Türkiye de dahil olmak üzere birçok ülkede eskiye dayandığı vurgulanarak bu muamelelerin önlenmeye çalışıldığına inanılmaktadır. 90 günlük gözaltı süresinin kısaltılacağı belirtilmiştir. Türkiye'de basın hürriyetinin olduğu, ancak Sıkıyönetim Komutanlıkları'nın kullandıkları yetkilerle bazı gazetelerin kısa süreli kapatıldığı görülmüş ve basın oto sansür uygulamak durumunda kalmıştır. Fakat yine de Türk basınının oldukça rahat hareket ettiği görülmüş ve De Coster'ın görüştüğü kişilerden biri olan Ecevit'in Arayış adlı dergisinde "görüşlerini serbestçe yazabildiği"ni ${ }^{58}$ aktarmıştır. Kurucu Meclis genel bir seçimle oluşturulmayacaktır. Son söz sahibi MGK olacak ve sonunda referandum yapılacaktır. De Coster böyle bir uygulamanın birçok ülkede yapıldı̆̆ını belirterek buna itiraz edilmemesi gerektiğini savunmuştur. Eski parlamenterlerin Kurucu Meclise katılmalarına Evren'in olumlu yaklaşmadığını aktaran De Coster eski parlamenterlerin tecrübelerinin önemini vurgulamıştır. Anayasa ile çok fazla ayrıntı paylaşılmamış, fakat De Coster Cumhurbaşkanı yetkilerinin artırılacağının söz konusu olduğunu belirtmiştir. Ayrıca anayasanın referanduma sunulmadan önce geniş bir şekilde kısıtlama getirmeden tartışılacağının belirtildiğini kaydetmiştir. De Coster seçim tarihinin Ekim veya Kasım aylarında açıklanacağını belirterek en geç 1983 sonbaharında genel seçimlerin yapılacağını bildirmiştir. De Coster son

\footnotetext{
52 “Avrupa Konseyi Tüzük Komisyonu, Türk Üyelerin Göreve Devamını Karalaştırdı”, Milliyet, 24 Mart 1981, s. 7.

${ }^{53}$ Altan Öymen, "Komisyonda Alınan Sonuç", Cumhuriyet, 26 Mart 1981, ss. 1, 7.

${ }^{54}$ Oktay Ekşi, "Gündemde Olmak", Hürriyet, 25 Mart 1981, s. 1.

${ }_{55}$ Oktay Ekşi, "Ne Siyah Ne de Pembe Gözlük", Hürriyet, 31 Ocak 1981, s. 1.

${ }^{56}$ Nazlı Ilıcak, "Türkiye ve Avrupa", Tercüman, 25 Mart 1981, ss. 1, 12.

57 “Avrupa Parlamentosu Asamble Başkanı Ankara'ya Geldi...”, Milliyet, 13 Nisan 1981, s. 6.

${ }^{58}$ Ancak dergi, 2 Mart 1982 tarihinde Ankara Sıkıö̈netim Komutanlığı tarafından 1402 sayılı Sıkıyönetim Yasası'nın

3. maddesi C bendi uyarınca süresiz kapatılmıştır. Bkz. "Arayış Dergisi Süresiz Kapatıldı”, Milliyet, 3 Mart 1982, s. 1 .
} 
olarak Türkiye ile Avrupa Konseyi arasındaki ilişkilerin olumlu seyir izlemesi konusunda görüşlerini aktarmış ve Türkiye'nin üyelikten çıkarılmamasını savunmuştur. ${ }^{59}$

Başkanlık Divanı yaptıkları toplantıda De Coster'ın hazırladığı raporu görüşerek Türkiye'nin Konsey üyeliğinin devamı ve Türk parlamenterlerin görev süresinin uzatılması konusunda görüş birliği sağlamıştır. Varılan görüşün De Coster'ın “Faaliyet Raporu”na eklenerek 11 Mayıs 1981 tarihinde AKPM'ye sunulmasına karar verilmiştir. ${ }^{60} 11$ Mayıs 1982 tarihinde yapılacak Avrupa Konseyi toplantısı henüz yapılmadan ve Türkiye hakkında kesin karar verilmeden Türkiye bir hamle yapmış ve Türk hükümeti tarafından yetki belgesi gönderilmeyen Konsey üyesi eski Türk parlamenterleri 30 yıldır ilk defa Avrupa Konseyi 33. dönem toplantılarına katılmamıştır. ${ }^{61} 11$ Mayıs'ta Avrupa Konseyi'nde Türkiye konusundaki görüşmeler yapılmış ve aynı gün toplanan Siyasi İşler Komisyonu'nda Türkiye'nin Konsey'de kalması, ancak Türk parlamenterlerin görev sürelerinin uzatılmaması görüşü benimsenmiştir. ${ }^{62}$ Ancak yine de bu konu Konsey üyeleri arasında bölünmelere neden olmuş ve Komisyon 14 Mayıs'ta toplanacak olan AKPM'ye Türkiye için rapor hazırlayamamıştır. ${ }^{63} 14$ Mayıs 1981 tarihinde AKPM'de Türkiye konusu üzerine görüşmeler yapılmış ve oylama sonucunda Türkiye'nin Konsey üyeliğinin devam etmesine, ancak Türk parlamenterlerin görev süresinin uzatılmamasına karar verilmiştir. Üyeliğin devamı konusu ise 1982 yılının Ocak ayına kadar gözlemlenecek olan Türkiye'nin ortaya koyacağı demokratik gelişmelere bağlı olarak yeniden ele alınacaktır. AKPM, Türkiye'ye verilen bu sürenin "son bir süre" olduğunun da altını çizmiştir. Parlamentodan çıkan karara göre Siyasi İşler Komisyonu Türkiye'deki insan hakları, temel özgürlükler ve demokrasiye dönüş konularındaki gelişmeleri takip ederek rapor hazırlayacak; Hukuk İşleri Komisyonu sürecin hukuksal yönlerini inceleyecek; Konseyin 33. dönemin ikinci toplantısında yani sonbaharda bu konular yeniden gündeme alınacaktır. Ayrıca kararda, sonbahar dönemine kadar Türkiye'de anayasa tasarısının hazırlanacağı göz önünde bulundurularak diğer tüm demokratik gelişmelerin 1şı̆̆ında Avrupa Konseyi Bakanlar Kurulu'na yeni bir tavsiye kararı sunma hakkının saklı tutulduğu belirtmiştir. ${ }^{64}$

Avrupa Konseyi'nin 14 Mayıs tarihli toplantısında alınan karaların ardından Türk hükümeti de bildiri yayınlamış ve Konsey'de Türk parlamenterin görev süresinin uzatılmaması yönünde alınan kararın Türk hükümetinin görüşü doğrultusunda olduğu beyan edilmiştir. Bildiride bu karara yönelik olarak, "Bu karar Avrupa Konseyi ile ilişkilerimizin özüne tesir etmemekte olup, kurumsal münasebetlerimizin devam edeceği şüphesizdir." ifadesi yer almıştır. Ancak bildiride, Avrupa Konseyi toplantılarında Türk kamuoyu ve yönetimi üzerinde baskı kurma çabaları içeren eleştirilerin kabul edilemeyeceği de belirtilmiştir. ${ }^{65}$ Gelişmeleri yorumlayan Cumhuriyet gazetesi yazarı Altan Öymen'e göre önemli olan ve beklenilen kararın Türkiye'nin üyeliğinin devam etmesiydi. Zira Türk hükümeti de bu isteğini s1k sık dile getirmişti. Fakat Türk parlamenterlerin görev süresinden umutlu olmayan Türk hükümeti bu konuda önce kendisi adım atmış ve parlamenterlerin yetki belgelerini yazmamışt. Altan Öymen Türk hükümetinin bu tutumunu isabetli bir karar olarak değerlendirmiştir. Altan Öymen'e göre Türk hükümeti böylelikle, "Benim bu üyeler hakkında zaten bir talebim yoktu ki.. Ben de parlamentonun geçici olarak mevcut olmadığı bir sırada Konsey'e parlamenter göndermenin mümkün olduğu kanısında

\footnotetext{
59 “De Coster: 'MGK, Başkanlık Rejimi Getirmek İstemiyor”, Milliyet, 28 Nisan 1981, s. 6.

60 “Avrupa Konseyi Başkanlık Divanı Türkiye’nin Üyeliğinin Devamı İçin Görüş Birliğine Vardı”, Tercüman, 30 Nisan 1981, ss. 1, 9.

61 “Türk Üyeler Konsey'in Türkiye Görüşmelerine Katılamıyor”, Cumhuriyet, 12 Mayıs 1981, s. 1.

62 “Türkiye ile İlgili Karar Oylaması Ertelendi”, Milliyet, 12 Mayıs 1981, s. 1.

63 “Asamble Türkiye'yi Görüşüyor”, Tercüman, 14 Mayıs 1981, ss. 1, 9.

64 “Konsey Üyeliğimiz Sürecek”, Cumhuriyet, 15 Mayıs 1981, ss. 1, 5.; Council of Europe-Parliamentary Assembly, Term of Office of The Turkish Parliamentary Delegation, Order 398, http://assembly.coe.int/nw/xml/XRef/XrefXML2HTML-en.asp?fileid=13604\&lang=en, (04.05.2020).

65 “Türkiye Avrupa Konseyinde Kaldı", Tercüman, 15 Mayıs 1981, ss. 1, 8.
} 
değildim. Ama siz isteseydiniz ona da bir itirazım olmayacaktı." diyebilme rahatlığını elde etmeyi sağlamıştır. ${ }^{66}$ Milliyet gazetesi yazarlarından ve aynı zamanda Avrupa Konseyi üyesi eski Türk parlamenterleri arasında yer alan Metin Toker ise, Mayıs ayında yapılan görüşmelerin esas konusunun Türkiye'nin üyeliğinin olmadığı vurgusunu yapmıştır. Eylül 1980'den beri Türkiye'nin üyeliğinin devam edip etmeyeceği konusundaki kararın Konsey tarafından sürekli ertelendiğine dikkat çeken Toker, Mayıs ayındaki görüşmede de kararın Eylül-Ekim dönemi toplantısına erteleneceğinin belli olduğuna dikkat çekmiştir. Toker, Mayıs ayındaki asıl görüşme konusunun Türk heyetinin görev süresine ilişkin olduğunu belirtmiştir. Ancak heyetin görev süresinin uzatılıp uzatılmasının ise bir önem taşımadığının altını çizmiştir. ${ }^{67}$ Ara rejim döneminde Türkiye ile Batı arasındaki ilişkiler değerlendirildiğinde Türkiye'nin Batı'nın üyesi olmasına rağmen bu dönemde Batı'nın Türkiye'ye soğuk yaklaşması kırıcı bir tutum olarak yorumlanmıştır. Milliyet gazetesi yazarlarından Çetin Altan da Türkiye'nin Batı için taşıdığı stratejik önemin üzerinde durmuştur. Çetin Altan, "Orta Doğu dengesinin kilit taşı" olarak nitelendirilen Türkiye'nin Avrupa'dan ayrılması durumunda bu niteliğini kaybedebileceğine dikkat çekmiştir. Kilit taşında meydana gelecek bir sallantının da Yunanistan'ı kendi bölgesinde bir baskı ile karşı karşıya bırakacağının altını çizmiş ve Yunanistan'ın bu baskıyı kaldıramayacağını belirtmiştir. Eğer bu iki durum gerçekleşirse, İsrail'i Yakın Doğu'da ileri bir karakol olarak bulundurmak isteyen Batı'nın "İsrail manivelasını" çalıştıramayacağına vurgu yapmıştır. Tüm bunlar göz önünde bulundurulduğunda mevcut dengedeki bozulmanın Türkiye'den ziyade diğer grupları daha çok zarara sokacağını ifade etmiştir. ${ }^{68}$

\section{Avrupa Konseyi'nin Türkiye'deki Siyasi Gelişmelere Yaklaşımı ve Türkiye'nin Konsey Üyeliği Sorunu}

Avrupa Konseyi'nin Mayıs ayı oturumundan sonra Eylül-Ekim dönemi toplantısına kadar geçen süreçte MGK tarafından demokrasiye geçiş için ilk adım olarak sunulan Kurucu Meclis Kanunu kabul edilmiştir. ${ }^{69}$ Türkiye'deki bu gelişmeler yine Steiner tarafindan takip edilmiş ve Steiner Avrupa Konseyi'nin Eylül-Ekim dönemi için rapor hazırlamıştır. AKPM 30 Eylül-8 Ekim 1981 tarihleri arasında toplanacak ve 3 Ekim günü gündemine Steiner'1n Türkiye'deki gelişmeleri konu alan raporunu görüşecektir. Steiner hazırladığı raporda, Türkiye'nin Konsey üyeliğine ilişkin kararın Ocak 1982'de yapılacak olan toplantıda verilmesini ve bu süreç içerisinde Türkiye'de incelemelerin devam etmesini önermiştir. Steiner, raporunda Türkiye'de Kurucu Meclis yasasının yayınlanmasını demokrasiye dönüş için verilen söz kapsamında önemli bir gelişme olarak göstermiştir. Ancak Steiner, Kurucu Meclis üyelerinin seçim sistemi hususunda karmaşıklığın olduğunu da belirtmiştir. Raporda Türkiye yanlısı bir tutum sergilenmesine rağmen Türkiye'deki durumun Avrupa Konseyi statüsü ile çeliştiğinin altı çizilmiştir. ${ }^{70}$

AKPM 3 Ekim 1981 tarihli oturumunda Steiner'ın hazırladığı Türkiye'deki gelişmeleri içeren raporu görüşmüştür. Genel olarak bakıldığında Meclis’teki Muhafazakâr grup Türkiye'deki yönetimi anlayışla karşılama eğiliminde olmuş ve demokratik kurallara uygun olmasa da Kurucu Meclis'in toplanacak olmasını demokrasi için atılan somut bir adım olarak değerlendirmiştir. Sosyal Demokrat ve Sosyalistler arasında ise bir an önce Türkiye hakkında karar vermesini savunanlar olsa da Türkiye'nin üyeliğine ilişkin kararın Ocak 1982'ye bırakılması görüşü hakim

${ }^{66}$ Altan Öymen, “Avrupa Konseyi Türkiye İçin Gerçekçi Bir Karar Aldı”, Cumhuriyet, 16 Mayıs 1981, ss. 1, 5.

${ }^{67}$ Metin Toker, "Biz Kendi İşlerimize Bakalım”, Milliyet, 17 Mayıs 1981, s. 8.

${ }^{68}$ Çetin Altan, "Türkiye’yi Avrupa'dan Saymamanın Ne Yararı Vardır ki...”, Milliyet, 27 Eylül 1981, s. 7.

${ }^{69}$ Milli Güvenlik Konseyi Tutanak Dergisi, C. 3, 61'inci Birleşim, 29.6.1981, s. 583.

70 “Avrupa Konseyi Steiner'in Son Raporunu 3 Ekim'de Tartışacak”, Cumhuriyet, 28 Eylül 1981, ss. 1, 7.; "Steiner, Türkiye’nin Üyeliğinin Ocak Ayında Ele Alınmasını Önerdi”, Cumhuriyet, 29 Eylül 1981, ss. 1, 7.; “Steiner'ın Karar Tasarısı Bugün Görüşülüyor”, Cumhuriyet, 30 Eylül 1981, s. 1. 
olmuştur. ${ }^{71}$ AKPM, Siyasi İşler Komisyonu'nun sunduğu tasarının 6 maddesinin 2'sinde değişiklik yaparak tasarıyı büyük bir çoğunlukla kabul etmiştir. Yapılan değişikliklerde 11 Eylül 1980 tarihi öncesinde siyasi parti temsilcisi veya üyelerinin ilk genel seçimlerde aday olmalarının engellenmemesi yönünde ibare eklenmiş ve Türk hükümetinden tutuklulara yapılan kötü muamelenin durdurulması istenmiştir. Türkiye'nin Konsey üyeliğinin devam edip etmeyeceği konusundaki karar Konsey'in 24 Ocak 1982 tarihinde yapacağı toplantıya ertelenmiştir. 7 Aralık 1981 tarihinde Siyasi İşler ve Hukuk İşleri Komisyonu'ndan oluşan bir heyetin Türkiye'ye gelerek incelemelerde bulunması ve bunun sonucunda hazırlanacak raporun 24 Ocak'ta ele alınmasına karar verilmiştir. ${ }^{72}$ Alınan en dikkat çekici karar ise "Türkiye'deki durumun Avrupa Konseyi statüsü ile çeliştiği"nin açık bir şekilde yer almasıdır. ${ }^{73}$

Danışma Meclisi 23 Ekim 1981 tarihinde açılmıştır. ${ }^{74}$ Ancak 1981 yılının sonlarına doğru Avrupa Konseyi-Türkiye ilişkileri, her iki taraf açısından da sabırsız ve hoşgörüsüz bir noktaya varmıştır. Konsey için Türkiye, demokrasiyi yeniden tesis etme adına bir kanıt göstermemişti. Danışma Meclisi açılmış olmasına rağmen işkence "iddiaları" yayılmış, toplu davalar açılmış, 52 idam cezası talep edilmiş, siyasi partiler kapatılmış ve eski CHP Genel Başkanı Bülent Ecevit hapse mahkum edilmişti. Konsey'in tavrı Türkiye için baskıya dönüşmeye başlamış ve bu durum Türk yetkililer için kabul edilemez bir hal almıştı. ${ }^{75}$ Böyle bir ortam içerisinde Başbakan Bülend Ulusu yaptığı bir basın toplantısında Avrupa Konseyi için “...İstenmeyen kimseyle beraber çalışmak arzusunda değiliz, belki de buna lüzum kalmaz. Biz çıkarız oradan, eğer böyle bir hava varsa." ifadelerini kullanmıştır. ${ }^{76}$ Ulusu'nun bu açıklaması, Avrupa baskılarına karşı artan sabırsızlığın yansıması olarak değerlendirilmiştir. Ancak yine de gerçekleştirilmesi pek olası olmayan bir tepki olarak görülmüştür. Konsey'den çıkmak, Türkiye'nin Kemalist devlet ideolojisinin temel taşı olan Batılılaşmadan ve Batı'nın siyasi ve ideolojik bağlarından kopma anlamına gelecekti. Bu durum aynı zamanda Türkiye'nin diğer Avrupa kuruluşlarıyla da ilişkilerini ve itibarını etkileyecekti. Bunların yanı sıra Konsey'den çıkarılma konusu Türkler için Türkiye'nin Avrupalılığının bir sınavı olarak görülmüştür. Tüm bunlar göz önünde bulundurulduğunda askeri yönetimin Avrupa ile uzlaşmaya mecbur olduğu ifade edilmiştir. ${ }^{77}$ Ulusu'nun açıklamasından sonra Cumhuriyet gazetesinde de, Batılı kurumlar arasında Avrupa Konseyi'nin özel bir yeri olduğuna vurgu yapılmış ve Avrupa Konseyi'nden ayrılmanın Türkiye'nin diğer Avrupa toplulukları ile ilişlerini olumsuz etkileyebileceği belirtilmiştir. Ulusu'nun "eğer istenmiyorsak çıkarız" ifadesini kullanmasına rağmen Türkiye'nin Batı kurumları içerisinde kalma isteğinin bilindiğinin altı çizilmiştir. Bu noktada demokrasiye dönüş kapsamında bir takvimin Ocak 1982 içerisinde açıklanması olası görülmüştür. Zira Avrupa Konseyi'nin Türkiye ile ilgili kararını Ocak 1982'de verecek olması da önemliydi. ${ }^{78}$

\section{1. “Demokrasi Takvimi”nin Avrupa Konseyi ile İlişkilere Etkisi}

Avrupa Konseyi ile Türkiye arasındaki ilişkiler 1981'in sonlarına doğru gerilmeye başlamışken Kenan Evren 30 Aralık 1981 tarihinde demokrasi takvimine yönelik açıklama

\footnotetext{
71 “Avrupa Konseyi, Türkiye’nin Üyeliğini Ocak Ayında Karara Bağlayacak”, Milliyet, 4 Ekim 1981, s. 9.

72 “Konsey Türkiye İle İlgili Tasarıyı Kabul Etti”, Hürriyet, 6 Ekim 1981, ss. 1, 11.

73 “Türkiye'nin Avrupa Konseyi Üyeliği Ocakta Görüşülecek”, Milliyet, 6 Ekim 1981, s. 8.; Council of EuropeParliamentary Assembly, Resolution http://semanticpace.net/tools/pdf.aspx?doc=aHR0cDovL2Fzc2VtYmx5LmNvZS5pbnQvbncveG1sL1hSZWYvWDJILURXLWV4 dHIuYXNwP2ZpbGVpZD0xNjE2OCZsYW5nPUVO\&xsl=aHR0cDovL3NlbWFudGljcGFjZS5uZXQvWHNsdC9 QZGYvWFJIZi1XRC1BVC1YTUwyUERGLnhzbA==\&xsltparams=ZmlsZWlkPTE2MTY4, (05.04.2020).

74 "Danışma Meclisi Törenle Açıldı", Cumhuriyet, 24 Ekim 1981, s. 1.

${ }^{75}$ Dağı, agm, pg. 132.

76 “Ulusu: İstenmiyorsak, Avrupa Konseyi’nden Kendimiz Çıkarız”, Cumhuriyet, 8 Aralık 1981, s. 1.

77 Dağı, agm, pg. 133.

78 "Demokrasi ve Türkiye", Cumhuriyet, 8 Aralık 1981, ss. 1, 9.
} 
yapmış ve anayasa halkoylamasının 1982 sonbaharında, seçimlerin de 1983 sonbaharında yapılacağını, ancak anayasa hazırlanması konusunda bir gecikme olursa seçimlerim 1984 ilkbaharında yapılacağını duyurmuştur. ${ }^{79}$ Evren'in takvim açıklaması Cumhuriyet gazetesi tarafından "beklenen konușma" olarak değerlendirilmiștir. Evren'in bu açıklamasının iç ve dıș kamuoyunun yanı sıra özellikle Avrupa'nın beklentilerine bir cevap niteliği taşıdığı vurgulanmıştır. Zira açıklama, demokrasiye dönüş konusunda belirsizlikleri giderme yönünde atılmış olumlu bir adım olarak görülmüsstür. ${ }^{80}$ Türkmen de takvimin Avrupa Konseyi'nin endişelerini giderme konusunda etkili olacağını beklediklerini ifade etmiştir. ${ }^{81}$ Evren'in açıklamasının Batılı diplomatlarda oldukça olumlu bir etki yarattığı aktarılmıştır. Batılı diplomatlara göre Evren'in demokrasiye dönüş konusunda somut bir açıklama yapması beklenen bir durumdu, ancak seçim tarihini de içerecek şekilde detaylı bir takvim verilmesi tahmin edilmemişti. Bu şekilde kapsamlı bir takvim verilmesinin Batılı ülkelerin parlamentolarında da olumlu etki yaratacağına dikkat çekilmiştir. ${ }^{82}$ Ancak takvimin açıklandığı tarihlerde Polonya ile ABD-Avrupa arasındaki ilişkilerin gündemde ağırlık kazanması ve Evren'in açıklamasının yılbaşı yani tatil dönemine denk gelmesi demokrasi takviminin beklenen etkiyi yaratmasına engel olmuştur. Takvimin açıklanma tarihinin üzerinden bir hafta geçmiş olmasına rağmen Türkiye konusu Avrupa'nın gündeminde dahi olmamıştır. ${ }^{83}$

Avrupa Konseyi'nden 7 Aralık 1981 tarihinde gelmesine karar verilen heyet Türkiye'ye 7-14 Ocak 1982 tarihleri arasında gelmiş ve incelemelerde bulunmuştur. ${ }^{84}$ Avrupa Konseyi heyeti temcilerinin temaslarının ardından Türkmen, Türkiye'nin Avrupa Konseyi ile olan ilişkilerine önem verdiğini belirtmiş ve Avrupa Konseyi sözleşmeleri ile buna bağlı anlaşmalarda tanımlanan demokratik hak ve özgürlüklere bağl1 olduğunu ifade etmiştir. ${ }^{85}$ Temsilcilerin Türkiye'deki görüşmeleri ve görüşmeler neticesinde hazırlayacakları raporun nasıl sonuçlar getireceği Türk kamuoyu tarafindan dikkatle takip edilmiştir. 25 Ocak 1982'de AKPM'de Türkiye için yapılacak olan oylama, Milliyet gazetesi tarafından Türkiye'nin Tanzimat'tan beri davam eden "Avrupalı olma" gayreti yönünde geçireceği "ciddi sınavlardan" biri olarak değerlendirilmiştir. ${ }^{86} 25$ Ocak 1982'de AKPM, Steiner'ın hazırladığı rapor doğrultusunda Türkiye'deki gelişmeler ve Türkiye'nin Konsey üyeliği konusunu ele almaya başlamıştır. ${ }^{87}$ Örsan Öymen'e göre demokrasi takviminin açıklanmış olması Konsey'deki çoğu olumsuz sesi susturmuştu, ancak insan hakları konusunda aynı sonucu getirmemiştir. ${ }^{88}$ Siyasi İşler Komisyonu üyelerine sunulan rapor, "karar tasarısı", "tavsiye kararı" ve "direktif tasarısı" olmak üzere 3 bölümden oluşmuştur. Raporun "karar tasarısı" bölümü, Siyasi Komisyon üyelerinin sol kanat parlamenterleri tarafından ilave edilen iki madde ile sertleştirilerek kabul edilmiştir. Bu maddeler, "Türkiye'nin Konsey'de kalmasına karşılık insan haklarının bu ülkede ne derece ihlal edildiğinin belirlenmesi için İnsan Hakları Komisyonu'na başvurulması" ve "Türkiye'nin insan haklarını ihlal etmesi nedeniyle kınanması" şeklindedir. Bu maddelerin eklenmesinden sonra Steiner ise raporun kendi raporu olmaktan çıktığını vurgulayarak sol parlamenterlere sert bir tepki göstermiştir. Hürriyet gazetesi, Siyasi Komisyon'da yaşanan bu olayı "Komisyonda yine entrika döndü” başlığıyla aktarmıştır. ${ }^{89}$

\footnotetext{
79 "Daha Aydınlık Günlere", Hürriyet, 31 Aralık 1981, s. 1.

80 "Demokrasi Takvimi”, Cumhuriyet, 31 Aralık 1981, ss. 1, 9.

81 “'Demokrasi Takvimi, Avrupa Konseyi’nin Endișelerini Gidermiş Olmalıdır”, Tercüman, 8 Ocak 1982, s. 1.

82 “Ankara'daki Yabancı Diplomatlar Görüşlerini Açıkladı: Org. Evren’in Açıklaması Olumlu, Yapıcı ve Ümit Verici Olarak Değerlendirildi", Milliyet, 31 Aralık 1981, s. 14.

${ }^{83}$ Mehmet Ali Birand, "Polonya Toz Bulutu Arasında, Türkiye'nin Demokrasi Takvimi”, Milliyet, 8 Ocak 1982, s. 9.

84 “Avrupa Konseyi Danışma Meclisi Bugün Türkiye’yi Ele Alacak”, Milliyet, 25 Ocak 1982, s. 8.

85 “Türkmen: 'Türkiye, Avrupa Konseyi İle İlişskilerine Önem Vermektedir'”, Milliyet, 9 Ocak 1982, s. 8.

${ }^{86}$ Mehmet Barlas, "Kulüp Üyeliği mi?", Milliyet, 12 Ocak 1982, s. 1.

87 “Avrupa Konseyi Danışma Meclisi Türkiye Konusunu Görüşmeye Yarın Başlıyor”, Tercüman, 24 Ocak 1982, s. 1.

${ }^{88}$ Örsan Öymen, "Gene İnsan Hakları", Milliyet, 23 Ocak 1982, s. 9.

89 “Steiner Raporu Değiștiriliyor", Hürriyet, 26 Ocak 1982, ss. 1, 13.
} 
Raporda Türkiye'deki durumun Avrupa Konseyi statüsü ile çeliştiği kabul edilmiş, Türkiye'de insan hakları sorunu ve demokrasiye dönüş takvimi öne çıkan iki önemli kaygı verici husus olarak değerlendirilmiştir. Raporda yer alan ifadeye göre Türk hükümeti ve halkı Konsey'de kalmayı istemekte ve önemsemekteydi. Bu durum Konsey için Türkiye'deki gelişmeleri etkileyebilme adına büyük bir olanak görülmüss ve Türkiye'nin Konsey'de kalması gerektiği rapor edilmiştir. Raportörlerin tavsiye kararında Türkiye'deki iç durumun takip edilmesi ve Meclis'e rapor edilmesi, tüm imkanların kullanılarak ve insan haklarına saygı göstermesi de dahil edilerek Türkiye'nin tam demokrasiye dönmesi için yardım edilmesi yer almıştır. Direktif tasarısında ise Meclis, Hukuk İşleri Komisyonu ve Siyasi İşler Komisyonu'nu insan hakları konusu başta olmak üzere Türkiye'deki gelişmeleri ve yeni anayasanın hazırlık çalışmalarını dikkatle izlemelerine devam etmekle ve en geç 1982 sonbaharında yeni bir rapor hazırlamakla görevlendirmiştir. ${ }^{90}$

Siyasi İşler Komisyonu'nda Türkiye'deki işkence “iddiaları”na ilişkin hususun incelenmesi için rapora eklenen İnsan Hakları Komisyonu'na başvurma hakkı ve Uluslararası Kızılhaç heyetine Türkiye'deki cezaevi koşullarını objektif bir şekilde soruşturma yetkisi ${ }^{91}$, hem Steiner'ın hem de Türk kamuoyunun tepkisine neden olan maddeler arasında yer almıştır. ${ }^{92} \mathrm{Bu}$ maddeler Tercüman gazetesinde, Türkiye'yi Konsey'den çıkarmaya mecbur bırakmak için oynanan bir "oyun" olarak değerlendirilmiştir. ${ }^{93}$ Milliyet gazetesi bu gelişmeler üzerine Avrupa Konseyi ile ilişkilerin bitebileceğine dikkat çekmiştir. Zira Siyasi İşler Komisyonu'nun Parlamenter Meclisi'ne sunmak üzere kabul ettiği karar tasarısının sorumsuzluk örneği olduğunu, “Türkiye'nin birtakım şahısların şamar oğlanı olmadığını” ve Kızılhaç da dahil olmak üzere hiç kimsenin Türkiye'yi teftiş etme haddinin olmadığını özellikle vurgulamıştır. ${ }^{94}$ Konsey'deki bu gelişmelere daha makul yaklaşan Hürriyet gazetesi yazarı Oktay Ekşi ise Türkiye'nin Konsey'den ihraç edilmesini isteyen üyelerin çoğunluk sağlayamamaları nedeniyle İnsan Hakları Komisyonu'na başvurma eğilimi taşıdıklarını belirtmiştir. Oktay Ekşi’ye göre İnsan Hakları Komisyonu'nca bir soruşturma başlatılsa dahi bunun tamamlanması iki yılı bulacaktır ve bu süreçte Türkiye zaten demokratik düzene dönmüş olacaktır. Bu nedenle Konsey'deki durumu Türkiye açısından çok olumsuz değerlendirmemiştir. ${ }^{95}$

\footnotetext{
90 “Komisyon Raporu: Türkiye’ye Ekime Dek Süre Tanınmalı”, Cumhuriyet, 26 Ocak 1982, ss. 1, 9.; “ “Ankara ile İlişki Sürmeli' ”, Milliyet, 26 Ocak 1982, s. 9.; Council of Europe-Parliamentary Assembly, Situation in Turkey, Order 406 , http://semanticpace.net/tools/pdf.aspx?doc=aHR0cDovL2Fzc2VtYmx5LmNvZS5pbnQvbncveG1sL1hSZWYvWDJILURXLWV4 dHIuYXNwP2ZpbGVpZD0xMzYxMiZsYW5nPUVO\&xsl=aHR0cDovL3NlbWFudGljcGFjZS5uZXQvWHNsdC9 QZGYvWFJlZi1XRC1BVC1YTUwyUERGLnhzbA==\&xsltparams=ZmlsZWlkPTEzNjEy, Resolution 765, http://semantic-

pace.net/tools/pdf.aspx?doc=aHR0cDovL2Fzc2VtYmx5LmNvZS5pbnQvbncveG1sL1hSZWYvWDJILURXLWV4 dHIuYXNwP2ZpbGVpZD0xNjE3NiZsYW5nPUVO\&xsl=aHR0cDovL3NlbWFudGljcGFjZS5uZXQvWHNsdC9Q ZGYvWFJ1Zi1XRC1BVC1YTUwyUERGLnhzbA==\&xsltparams=ZmlsZWlkPTE2MTc2, Recommendation 936, http://semantic-

pace.net/tools/pdf.aspx?doc=aHR0cDovL2Fzc2VtYmx5LmNvZS5pbnQvbncveG1sL1hSZWYvWDJILURXLWV4 dHIuYXNwP2ZpbGVpZD0xNDk3MCZsYW5nPUVO\&xsl=aHR0cDovL3NlbWFudGljcGFjZS5uZXQvWHNsdC9 QZGYvWFJ1Zi1XRC1BVC1YTUwyUERGLnhzbA==\&xsltparams=ZmlsZWlkPTE0OTcw, (05.04.2020).

91 Council of Europe-Parliamentary Assembly, Situation in Turkey, Resolution 765, http://semanticpace.net/tools/pdf.aspx?doc=aHR0cDovL2Fzc2VtYmx5LmNvZS5pbnQvbncveG1sL1hSZWYvWDJILURXLWV4 dHIuYXNwP2ZpbGVpZD0xNjE3NiZsYW5nPUVO\&xsl=aHR0cDovL3NlbWFudGljcGFjZS5uZXQvWHNsdC9Q ZGYvWFJIZi1XRC1BVC1YTUwyUERGLnhzbA==\&xsltparams=ZmlsZWlkPTE2MTc2, 17. 18. 19/d maddeleri, (05.04.2020).

92 "Siyasi Komisyon, Türkiye Aleyhinde 2 Önergeyi 6’ya Karş1 20 Oyla Reddetti”, Milliyet, 27 Ocak 1872, s. 8.

${ }^{93}$ Sedat Sertoğlu, “Türkiye İçin Yepyeni Bir 'Oyun' Sergileniyor”, Tercüman, 27 Ocak 1982, s. 1.

${ }^{94}$ M.T., ““Avrupa Konseyi İle İş Burada Bitebilir”, Milliyet, 27 Ocak 1982, s. 8.

95 Oktay Ekşi, “Avrupa Bizi Konuşurken...”, Hürriyet, 27 Ocak 1982, s. 3.
} 
Avrupa Konseyi Siyasi İşler Komisyonu'nda kabul edilen karar tasarısı 27 Ocak 1982 tarihinde AKPM'de görüşülmeye başlamıştır. Ancak raportör Steiner, Avrupa Konseyi tarihinde ilk defa yaşanan bir olay olarak kendi hazırladığı tasarıdan imzasını çekmiștir. ${ }^{96}$ edilirse Türkiye'nin Konsey üyeliğinden çekilme eğiliminde olduğunu iletmişlerdir. ${ }^{97}$ AKPM'de görüşmeler devam ederken Milliyet gazetesi dikkat çekici bir haber paylaşmıştır. 7-14 Ocak tarihlerinde Türkiye'de incelemelerde bulunan Avrupa Konseyi heyetinin Türk yetkililer ile yaptığı görüşmelerin öz dökümünün Siyasi ve Hukuk İşleri Komisyonu üyelerine gizli bir rapor ile sunulduğu paylaşılmıştır. 25 Ocak 1982 tarihinde sunulan (33) 10 sayılı raporda Evren'in Avrupa Konseyi heyetinin Türkiye'ye gelişini neden iki kez ertelediğine yer verilmiştir. Hatırlanacağı üzere heyet 7 Aralık 1981 tarihinde gelecekti. Evren'in, demokrasiye dönüş takvimini Avrupa Konseyi heyetinin baskısı sonucunda açıklandığına dair bir kanı oluşmaması için heyetin takvim açıklamasından sonra gelmesinin daha doğru olacağı düşüncesiyle hareket ettiği kaydedilmiştir. Ayrıca raporda Evren'in, AKPM'nin Türkiye ile ilişkileri olumsuz etkileyecek bir karar alması halinde Türkiye'nin başka gruplara ve bloklara yönelebileceğini vurguladığı belirtilmiştir. ${ }^{98}$

AKPM'de 28 Ocak 1982 tarihinde oylanan Türkiye raporu kabul edilmekle birlikte Türkiye'nin Konsey üyeliğinden çıkarılması 38'e karşı 75 oyla reddedilmiş ve demokratik gelişmelerin takibi için Türkiye'ye Ekim ayına kadar yeni bir süre verilmiştir. Raporda bazı ifadeler yumuşatılmakla beraber Avrupa İnsan Hakları Komisyonu'na başvurulabileceği kabul edilmiş; Türkiye'den Kızılhaç heyetinin inceleme yapmasına izin verilmesi; Türkiye'de demokratik sistemin yeniden kurulmasi; ifade özgürlüğünü, siyasal partiler ve sendikaların faaliyetlerini durduran ya da kısıtlayan kanunların yürürlükten kaldırılması; basın özgürlügünün sağlanması ve siyasi tutukluların serbest bırakılması istenmiştir. Ayrıca çıkarılmış olan bazı kanunlar örnek gösterilerek hazırlanacak olan anayasanın demokratik niteliğinden kaygı duyulduğu da raporda yer almıştır. ${ }^{99}$ Ancak demokrasi ve insan hakları konusunun dışında Türkiye'deki dini azınlıklara eşit davranılması ve bunların korunmasını talep eden bir ibarenin eklenmesi de dikkatleri çekmiştir. ${ }^{100}$ Mehmet Ali Birand Avrupa Konseyi’nin verdiği kararı, bulunan koşullar çerçevesinde olabilecek en yumuşak ve en iyi karar şeklinde değerlendirmiştir. Birand'a göre Konsey'den çıkan karar, Evren'in açıkladığı demokrasiye dönüş takvimine inanıldığını ve Evren'in sözünde duran bir kiși olduğunu göstermiștir. Ayrıca bu kararın, Türkiye'nin ve Türk halkının "hafife alınmadığının" da göstergesi olduğunu düşünmüştür. ${ }^{101}$ Nazlı Ilıcak da Avrupa Konseyi kararını genel olarak Türkiye'nin lehine bulmuş ve Türkiye'nin Konsey içerisinde kalmasını en önemli sonuç olarak yorumlamıştır. Ilıcak, raporda yer alan Kızılhaç'ın cezaevlerini incelemesi ve İnsan Hakları Komisyonu'na başvuru gibi yaptırımları içeren sertleştirilmiş maddeleri ise sadece teferruat olarak görmüştür. ${ }^{102}$

Türk basını Konsey'den çıkan karara daha sağduyulu bir yaklaşım sergilerken Ulusu, kararın Türkiye'ye karşı ağır ve haksız suçlamalar yönelttiğini belirterek Avrupa Konseyi'nin "düşmanca" bir tutum sergilediğini ifade etmiştir. Kararı sert bir şekilde eleştiren Ulusu, Türkiye'nin temsil edilmediği bir organ olan AKPM'yi kendilerine muhatap saymayacaklarını vurgulamıştır. ${ }^{103}$ Ulusu'nun bu açıklaması, Türkiye'nin Konsey'den ayrılma temayülü taşıdığını

\footnotetext{
96 “Avrupa Konseyi Danışma Meclisi’nde Türkiye Konusu Ele Alındı”, Milliyet, 28 Ocak 1982, s. 9.

97 "Ankara Konsey’den Çekilme Eğiliminde”, Milliyet, 28 Ocak 1982, ss. 9, 12.

98 “Evren'in Uyarıs1 Parlamenterlere Bildirildi”, Milliyet, 28 Ocak 1982, ss. 9, 12.

99 “Türkiye'ye Yeni Süre Tanındı”, Cumhuriyet, 29 Ocak 1982, ss. 1, 11.

100 "MGK, Avrupa Konseyi'nin Kararını Değerlendirdi”, Milliyet, 30 Ocak 1982, s. 8.

${ }^{101}$ Mehmet Ali Birand, "Çekinildiği Kadar Çıkmadı", Milliyet, 29 Ocak 1982, s. 9.

102 Nazlı Ilıcak, “Avrupa Konseyi”, Tercüman, 29 Ocak 1982, ss. 1, 14.

103 "Ulusu: Avrupa Konseyi’nin Suçlamaları Ağır ve Haksız”, Cumhuriyet, 31 Ocak 1981, s. 1.
} 
düşündürmüştür. Nazlı Ilıcak, Ulusu'nun açıklaması üzerine Konsey kararı hakkındaki düşüncelerini bir kez daha belirtmiş ve Türkiye'deki koşullara dikkat çekerek kararın oldukça olumlu olduğunu ifade etmiştir. Zira Avrupa Konseyi'nin temel prensibinin demokrasi ve özgürlük olduğu göz önünde bulundurulduğunda Ilıcak, Türkiye'deki mevcut koşulların bu prensipler ile çeliştiğini açıkça ortaya koymuş ve "hayal peşinde koşmak" yerine Konsey kararının kabul edilmesi yönünde çağrı yapmıştır. ${ }^{104}$ Kenan Evren de AKPM kararının ardından 31 Ocak 1982 tarihinde Radyo-Televizyon konuşması yaparak karara karşı tepkisini dünya ile paylaşmıştır. Evren Konsey'de gerçekleşen tartışmaların Türkiye'nin demokrasiye dönme kaygısı nedeniyle ortaya çıkmasından ziyade bazı parlamenterlerin kendi ülkeleri ile Türkiye arasındaki anlaşmazlıklara dayanarak Türkiye'ye saldırdıklarını beyan etmiştir. Evren, Ulusu'nun da belirttiği gibi Türkiye'nin temsilcisi bulunmayan bir organı muhatap saymayacaklarının altını çizmiştir. AKPM'deki bazı üyelerin tutumlarını Türkiye'nin içişlerine müdahale olarak değerlendiren Evren, bundan sonra AKPM'de Türkiye'ye yönelik iç müdahale niteliği taşıyan konuları gündem maddesi olarak kabul etmeyeceklerini ifade etmiş ve Avrupa Konseyi ile ilişkilerin hükümetlerin temsil edildiği Bakanlar Komitesi ve Delegeler Komitesi ile sürdürüleceğini açıklamıştır. Yani Evren Avrupa Konseyi'nden çekilmemiş, ancak Konsey ile olan ilişkilerin bundan böyle hükümetlerin tutumlarına göre şekilleneceğini ortaya koymuştur. ${ }^{105}$

Kenan Evren'in konuşmasından bir gün sonra önemli bir gelişme yaşanmıştır. Avrupa Konseyi raporunda öne çıkan maddelerden biri olan siyasi tutukluların serbest birakılması isteğine karşı1ık Türk yönetimi, Türkiye'de siyasi tutuklu bulunmadığını, tutuklanan kişilerin de terör, anarşi ya da devlete karşı işlenen suçlar kapsamında yargılandıklarını savunmuştu. ${ }^{106}$ Oysaki Ecevit'e, MGK'nın 52 sayılı kararına ${ }^{107}$ aykırı davrandığı gerekçesiyle Sıkıyönetim Komutanlığı 1 No'lu Askeri Mahkemesi tarafından üç ay hapis cezası verilmiş ve Ecevit 3 Aralık 1981 günü cezaevine girmişti. Ancak üç aylık süresi dolmadan 1 Şubat 1982 tarihinde serbest

Volume 12 Issue 6

December 2020 bırakılmıştır. ${ }^{108}$ Avrupa Konseyi ile Türkiye arasındaki ilişkilerin Türkiye'de demokrasinin yeniden tesisi üzerinde etkili olup olmadığı konusu 1982 'nin başlarında da tartışılan konular arasında yer almıştır. Evren'in 8 Şubat 1982 tarihinde Erzurum'da yaptığı açıklamasına baktığımızda demokrasiye Avrupa'nın baskısı sebebiyle değil, Türk milleti istediği ve Türk milletine yakışan bir yönetim şekli olduğu için dönüleceği vurgusu yapılmıştır. ${ }^{109}$ Evren'in bu ifadesi, demokrasiye dönme konusunda Avrupa tarafından bir baskı yapıldığını açıkça göstermektedir. İngiliz gazetelerinden The Times'ın haberinde de Evren'in demokrasiye dönmede kararlı duruşunun görüldüğü, ancak yine de Evren'e dış ülkelerden özellikle Batı Avrupa'dan kışlasına dönmesi yolunda sürekli baskı yapıldığı yer almıştır. ${ }^{110}$

\subsection{Anayasa Halkoylamasının ve 1983 Seçimlerinin Avrupa Konseyi Kararlarına} Etkisi

Türkiye'de yeni anayasa hazırlıkları tamamlanma aşamasına doğru ilerlerken AKPM Ekim 1982 dönemi toplantısını yapmıştır. 6 Ekim'de kabul edilen kararda Türkiye'den şu istekler yer almıştır: İnsan hakları temel ilkelerine uyulması, işkence "iddiaları" ile ilgili soruşturmaların

\footnotetext{
${ }^{104}$ Nazlı Ilıcak”, “Avrupa Konseyi'nden Çıkmak”, Tercüman, 31 Ocak 1982, ss. 1, 14.

105 "Evren Kükredi... 'Haysiyetimizden Taviz Vermeyiz”, Hürriyet, 1 Şubat 1982, ss. 1, 11.

106 “Ankara Konsey’den Çekilme Eğiliminde”, Milliyet, 28 Ocak 1982, ss. 9, 12.

${ }^{107}$ MGK 52 sayılı kararla "11 Eylül 1980 tarihinde, parlamento üyesi bulunan siyasi parti mensupları ile her kademede siyasi parti yöneticisi ve mensuplarının TÜRKIYE'nin geçmiş veya gelecek siyasi veya hukuki yapısıyla ilgili olarak kendi anlayışları doğrultusunda sözlü veya yazılı beyanda bulunmaları veya makale yazmaları ve bu amaçlarla toplantı yapmaları" yasaklanmıştır. Bkz. "Milli Güvenlik Konseyi Kararı", T.C. Resmi Gazete, 5 Haziran 1981, s. 2.

108 "Ecevit Tahliye Edildi”, Milliyet, 2 Şubat 1982, s. 12.

109 “Evren Erzurum'da Konuştu: 'Demokrasiyi Sizler İstediğiniz İçin Kuruyoruz”, Hürriyet, 9 Şubat 1982, ss. 1, 11.

${ }^{110}$ Peter Hopkirk, "A Special Report", The Times, 17 March 1982, pg. 1.
} 
sürdürülmesi ve işkence uygulamalarına son verilmesi; anayasada yer alan siyasi partiler, sendikalar, güçler ayrılığı ilkeleri ve temel hak ve özgürlüklere ilişkin maddelerin Avrupa İnsan Hakları Sözleşmesi'nde yer alan temel ilkelere uyumlu hale getirilmesi, Türkiye'deki dini azınlıkların korunması ve eşit muamele görmesi; anayasa halkoylamasının demokratik bir şekilde yapılması ve herkesin düşüncelerini serbestçe bildirmelerine imkan sağlanması. ${ }^{111}$

AKPM'nin bu istekleri ve uyarılarının ardından Türkiye'de 7 Kasım 1982 tarihinde hem yeni anayasa hem de cumhurbaşkanı seçimi için halkoylaması yapılmış ve \%90'ı aşan bir çoğunluk anayasayı kabul ederek ve Kenan Evren'in cumhurbaşkanlığını onaylamıştır. ${ }^{112}$ Anayasa halkoylaması sırasında Ankara'da gözlemci olarak bulunan Avrupa Konseyi Hukuk İşleri Komisyonu Raportörü Federal Alman Sosyal Demokrat Milletvekili Dr. Hans Bardens, Anayasa halkoylamasına ilişkin yaptığı değerlendirmede "güven ortamı içinde bir oylama" yapıldığını ve görebildiği kadarıyla da her şeyin demokratik olduğunu ifade etmiştir. ${ }^{113}$ Hem Hans Bardens hem de Avrupa Konseyi Hukuk İşleri Komisyonu Başkanı İngiliz Percy Grieve oy pusulalarının da zarflardan kesinlikle görünmediğini kaydetmişlerdir. ${ }^{114}$ Türkmen referandumun hemen ardından 10 Kasım 1982 tarihinde yapılan Avrupa Konseyi Bakanlar Komitesi toplantısına katılarak Türkiye'deki demokratikleşme süreci hakkında bilgi vermiştir. Türkmen, Türkiye'nin demokrasi aşamalarında son adıma geldiğini ve genel seçimlerin 1983 sonbaharında ya da en geç 1984 ilkbaharında yapılacağını belirtmiştir. ${ }^{115} \mathrm{Bu}$ gelişmeler doğrultusunda Türkiye'nin Konsey| üyeliğine ilişkin karar Ocak 1983 yılında yapılacak toplantıya ertelenmiştir. ${ }^{116}$

Avrupa Konseyi Türkiye Alt Komitesi ve Hukuk İşleri Komisyonu 11 Ocak 1983 tarihinde Paris'te toplanmış ve 26 Ocak 1983'te Strasbourg'da AKPM'de Türkiye'ye karşı ortaya koyacakları "kesin siyasi tutumu" belirlemeye çalışmışlardır. Türkiye Alt Komitesi toplantısında Steiner'ın hazırladığı rapor tasarısı görüşülmüştür. Steiner'ın karar tasarının çoğu maddesi görüşmeler sırasında sertleştirilmiş ve en dikkat çeken "Türkiye'nin Avrupa Konseyi Bakanlar Komitesi'nden demokrasiye tam olarak dönünceye kadar kendiliğinden çekilmesi” şeklindeki maddeyle birlikte tüm tasarı yapılan oylamada reddedilmiştir. Bu ret kararında hem Hans Bardens'in "1lımlı" sayılabilecek raporunun hem de oylamadan önce İlter Türkmen'in Ankara'da yaptığı konuşmada “AKPM, Türkiye'nin çoğulcu demokrasiye dönüş çalışmalarının son aşamasına girdiği bir dönemde olumsuz bir karar almakla tarihinin en büyük çelişkisine düşmüş olacaktır." şeklindeki ifadesinin etkili olabileceği düşünülmüştür. ${ }^{117} \mathrm{Bu}$ gelişmelerin sonrasında Avrupa Konseyi yeni Türk Anayasasının hukuksal değerlendirmesinin yapılması için Alman, İtalyan ve Danimarkalı üç anayasa uzmanını görevlendirmiştir. Uzmanlardan istenilen "Türkiye'de hazırlanan yeni anayasanın Avrupa Konseyi Sözleşmesi ve Avrupa İnsan Hakları Sözleşmesi'ne uygun mudur?” sorusunun araştırılması olmuştur. Uzmanların sunduğu raporlarda anayasanın bazı yönleriyle "ideal bir demokrasiden uzak olduğu" düşüncesinin öne çıktığı ve uygulamada ortaya çıkacak olan yaptırımların önem taşıyacağı kaydedilmiştir. ${ }^{118}$

111 Council of Europe-Parliamentary Assembly, Situation in Turkey, Resolution 786, http://semanticpace.net/tools/pdf.aspx?doc=aHR0cDovL2Fzc2VtYmx5LmNvZS5pbnQvbncveG1sL1hSZWYvWDJILURXLWV4 dHIuYXNwP2ZpbGVpZD0xNjE5NyZsYW5nPUVO\&xsl=aHR0cDovL3NlbWFudGljcGFjZS5uZXQvWHNsdC9Q ZGYvWFJlZi1XRC1BVC1YTUwyUERGLnhzbA==\&xsltparams=ZmlsZWlkPTE2MTk3, (05.04.2020).

112 "Yüksek Seçim Kurulu Kararı", T.C. Resmi Gazete, 9 Kasım 1982, s. 59.

113 "Güven Ortamı İçinde Bir Oylama Oldu", Tercüman, 9 Kasım 1982, ss. 1, 9.

114 “Türkiye'den Strasbourg'a Dönen Gözlemciler Halkoyundaki Olumlu İntibalarını Anlattılar”, Tercüman, 10 Kasım 1982, ss. 1, 11.

115 Council of Europe, Minutes of The 71st Session of The Committeeof Ninisters, 10 November 1982, https://rm.coe.int/native/09000016804d662a, pg. 26-32, (10.09.2020).

116 "Güven Ortamı İçinde Bir Oylama Oldu”, Tercüman, 9 Kasım 1982, ss. 1, 9.

117 "Avrupa Konseyi Komisyonları Türkiye Aleyhine Tasarıyı Reddetti”, Milliyet, 12 Ocak 1983, s. 6.

118 “Avrupa Konseyi’nin Anayasamıza İlişkin Raporlarını Açıklıyoruz”, Cumhuriyet, 21 Ocak 1983, ss. 1, 9. 
Steiner'in 11 Ocak 1983 'te görüşülen Türkiye hakkındaki tasarı kararının reddedilmesi üzerine Steiner Avrupa Konseyi'nde oylamaya sunulmak üzere yeni bir tasarı hazırlamıştır. Yeni tasarıda Türkiye'deki gelişmelerin umut vaat edici olduğu belirtilmiş, ancak yeni anayasanın ne demokratik ne de antidemokratik olduğuna vurgu yapılarak esas olanın uygulama sonucunda ortaya çıkacağına dikkat çekilmiştir. Uygulama noktasında da anayasayı demokratik ya da antidemokratik yapacak olan esas kıstasın ilk aşamada siyasi partiler kanunu olacağı belirtilmiştir. ${ }^{119}$ Steiner' in hazırladığı raporda Türkiye'nin Avrupa İnsan Hakları Sözleşmesi'yle tam olarak uyum sağlayamadığı, bunun sağlanması için serbest seçimle gelmiş bir parlamenter demokrasinin işlerliği ve insan haklarına saygının garanti edilmesi gerektiği vurgulanmıştır. Türkiye'de parlamenter demokrasi kurulana ve Türkiye AKPM'de yeniden temsil edilene kadar Türkiye'nin Bakanlar Komitesi'ndeki veto hakkından vazgeçmesi istenmiştir. ${ }^{120}$

AKPM, Türkiye'nin Konsey üyeliği konusunu tekrar tartışmak üzere Strasbourg'da 24 Ocak 1983 tarihinde toplanmıştır. ${ }^{121}$ Türk yönetimi tüm dünyaya demokrasi yolunda attıkları adımları ispatlamaya çalışırken ironik bir şekilde Avrupa Konseyi toplantılara başladığı sırada Cumhuriyet gazetesinin 1. Ordu ve İstanbul Sıkıyönetim Komutanlığı tarafından 1402 Sayılı Sıkıyönetim Yasası'nın 3/c maddesi uyarınca basımı, yayımı, dağıtılması ve bulundurulması veya taşınması, sıkıyönetim bölgesine sokulması yasaklanmıştır. ${ }^{122} 24$ Ocak-18 Şubat 1983 tarihleri arasında basımı olmayan Cumhuriyet gazetesinin temel kapatılma gerekçesi Türk basınında yer alamamıştır. Ancak The Times gazetesinin haberine baktığımızda asıl kapatılma gerekçesinin gazetenin 21 Ocak'ta Avrupalı uzmanların anayasa üzerine raporlarını yayınlaması olduğu açıklanmıştır. ${ }^{123}$ Avrupa Konseyi'nde Türkiye'nin ele alındığı oturumlarda çeşitli görüşler ortaya çıkmıştır. Türkiye lehine ve aleyhinde olmak üzere zit kutuplar görülmüştür. Hürriyet gazetesi, üyelerin Türkiye'deki durumu tartışacakları bu toplantıyı "Türkiye kavgası" olarak nitelendirmiştir. ${ }^{124}$ AKPM'de 27 Ocak 1983 tarihinde Türkiye'nin Konsey üyeliğine ilişkin oylama yapılmış ve Steiner'in tasarısı kabul edilmiştir. Ancak Türkiye'nin Bakanlar Komitesi'ndeki oy hakkından vazgeçmesini içeren madde reddedilmiştir. ${ }^{125}$ Konsey'in kabul ettiği kararda şu hususlar öne çıkmıştır: Halkoylaması ile hem anayasanın hem de cumhurbaşkanlığının kabul edilmiş olması ve anayasa için özgür tartışma ortamının sağlanmaması üzüntüyle karşılanmış; yeni anayasada insan haklarına ilişkin hükümlerin geniş sınırlamalar taşıdığı yer almış; Türkiye'nin henüz Avrupa Konseyi Statüsü ve Avrupa Konseyi İnsan Hakları Sözleşmesi ile tam uyumlu hale gelmediğinin altı çizilmiş ve özgürce seçilmiş bir parlamenter demokrasinin işlediğinin görülmek istendiği belirtilmiştir. Türkiye'den yeni anayasayı demokratik bir şekilde uygulaması, seçim yasası ve siyasi partiler yasalarının özgürce tartışlabilmeleri istenmiştir. Türkiye'nin Bakanlar Komitesi'ndeki oy hakkından vazgeçmesi konusu ve Türkiye'nin Konsey üyeliğinin devam edip etmeyeceğine yönelik kesin kararın Ocak 1984 'te verilmesi kabul edilmiştir. ${ }^{126}$

\footnotetext{
119 “Türkiye, Avrupa Konseyi’nin Gündeminde”, Milliyet, 23 Ocak 1983, s. 9.

120 Council of Europe-Parliamentary Assembly, Situation in Turkey, Resolution 794, http://semanticpace.net/tools/pdf.aspx?doc=aHR0cDovL2Fzc2VtYmx5LmNvZS5pbnQvbncveG1sL1hSZWYvWDJILURXLWV4 dHIuYXNwP2ZpbGVpZD0xNjIwNSZsYW5nPUVO\&xsl=aHR0cDovL3NlbWFudGljcGFjZS5uZXQvWHNsdC9Q ZGYvWFJIZi1XRC1BVC1YTUwyUERGLnhzbA==\&xsltparams=ZmlsZWlkPTE2MjA1, (05.04.2020).

${ }^{121}$ Avrupa Konseyi Parlamenterler Meclisi Bugün Strasbourg'da Toplanıyor”, Tercüman, 24 Ocak 1983, s. 1.

122 "Cumhuriyet ve Milli Gazete'nin Basım ve Yayımı Yasaklandı", Tercüman, 25 Ocak 1983, ss. 1, 14.

${ }^{123}$ Ian Murray Brussels, "Turkey Gets Reprieve in Europe”, The Times, 28 January 1983, pg. 6.

124 “Avrupa Konseyi’nde Türkiye Tartışması Başlıyor”, Hürriyet, 26 Ocak 1983, s. 13.

125 “Türkiye'ye Bir Yıl Daha Süre Tanındı”, Milliyet, 28 Ocak 1983, s. 8.

${ }^{126}$ Council of Europe-Parliamentary Assembly, Situation in Turkey, Resolution 794.
} 
Avrupa Konseyi'nin çeşitli alt komisyonları Eylül ayında Türkiye'yi yeniden gündemlerine almaya başlamışlardır. ${ }^{127}$ Alınan karara göre AKPM 26 Eylül-6 Kasım 1983 tarihleri arasında Strasbourg' da yeniden toplanarak Türkiye'yi ele alacaktır. Aslında Ocak 1983 'te alınan kararda Türkiye ilgili nihai karar için Ocak 1984 yılının beklenmesi ve 6 Kasım seçimlerinin takip edilmesi kaydedilmişti. ${ }^{128}$ Ancak Avrupa Konseyi'nin sonbahar oturumunda Steiner'in hazırladığı Türkiye'nin Konsey üyeliği ve 6 Kasım seçimlerinden sonra Türk parlamenterlerin Konsey'de temsil edilip edilmemesi konusunu içeren rapor ele alınmıştır. ${ }^{129}$ Konsey'de Türkiye konusu için 30 Eylül'de yapılan oylama sonucunda alınan kararda, görevlendirilecek üç bilim adamının Türkiye'de yürürlüğe giren yeni siyasi partiler kanunu, seçim kanunu, sendikalar ve basın kanunlarını ele alarak bunların Avrupa Konseyi İnsan Hakları Komisyonu'na ve Komisyon'un temel ilkelerine uyup uymadığını incelemeleri istenmiştir. Zira Konsey'in elde ettiği bilgilere göre 6 Kasım seçimlerinden sonra oluşacak parlamentonun demokratik bir nitelik taşımayacağı kanısı vardır. Avrupa Konseyi, Türkiye'nin Konsey üyeliği ve Türk parlamenterlerin Konsey'de yerlerini alıp almayacağı konusundaki kararını, Türkiye'deki gelişmeleri yılbaşına kadar yakından takip ettikten sonra vereceğini ve bu nedenle Ocak 1984'te yeniden oturum düzenlemeyi kabul etmiştir. ${ }^{130}$ Avrupa Konseyi'nin yeni seçilecek Türk parlamenterlere kuşkuyla yaklaşması Kenan Evren'in sert tepkisine neden olmuştur. Evren, ${ }^{131}$

Eğer Avrupa Konseyi bizi bu teşkilattan çıkarmıyorsa gücümüzü bilir. Kendisine lazım olduğumuzu bilir, onun için çıkarmaz. Çünkü o Türkiye'yi daima bir harpçi olarak tanımıştır. İkincisi de daima bugüne kadar olduğu gibi Osmanlı İmparatorluğu'nun son zamanlarında olduğu gibi Türkiye'nin içişlerine karışmayı kendine daima bir görev saymıştır. Eğer Avrupa Konseyi'nden Türkiye çıkacak olursa o zaman baskısını sürdüremeyecektir. Bu baskıyı devam ettirebilmek içindir ki Türkiye'yi Avrupa Konseyi'nden çıkarma cesaretini kendinde bulamamaktadır. Ama şunu bir defa daha burada tekrar edeyim ki Türkiye Cumhuriyeti, Avrupa Konseyi'ne dahil olmakla vücut bulmuş değildir. Türkiye Cumhuriyeti asırlar boyu vardır. Türk milleti Avrupa Konseyi içinde olsa da var olacaktır olmasa da var olacaktır.

ifadelerini kullanarak Türkiye'nin Konsey'den çıkarılamayacağından emin olduğunu göstermiştir. Mehmet Ali Birand'ın röportaj yaptığı Avrupa Konseyi Başkan Yardımcısı İngiliz Sir Fredric Bennett da Türkiye'yi desteklemesinde ülkesinin stratejik çıkarlarının etkili olduğunu belirtmiştir. Ortadoğu'daki çıkarları için Türkiye'nin yalnızlığa itilmesini bekleyen bir Sovyetler Birliği' nin olduğunu ifade eden Bennett, Türkiye'nin bölünmesini istemediğini ifade etmiştir. ${ }^{132}$

$\mathrm{Bu}$ arada Türkiye'de yaşanan siyasi gelişmelere baktığımızda partileşme süreci tamamlanarak 6 Kasım 1983 tarihinde milletvekili genel seçimleri yapılmıştır. Seçim sonucuna göre oyların yüzdelik olarak dağılım oranı sırasıyla Anavatan Partisi \%45,15, Halkçı Parti 30,46, Milliyetçi Demokrasi Partisi \%23,27, bağımsızlar \%01,12'dir. ${ }^{133}$ Türkiye'deki seçimleri izlemek üzere Ankara'ya Avrupa Konseyi üyesi yabancı milletvekilleri de gelmiştir. Milletvekilleri seçimlerin oldukça demokratik, herhangi bir baskıdan uzak yapıldığını ve Batı Avrupa demokrasisi düzeyinde gerçekleştiğini belirtmişlerdir. İzlenimlerini Avrupa Konseyi’ne rapor edecek olan

\footnotetext{
127 “Türkiye, Avrupa ve ABD’nin Gündemine Geliyor”, Milliyet, 5 Eylül 1983, s. 9.

128 “Avrupa Konseyi Genel Kurulu’nda Türkiye Görüşülecek”, Milliyet, 8 Eylül 1983, s. 8.

129 “Avrupa Konseyi Türkiye'nin Temsilini Bugün Oylayacak”, Cumhuriyet, 29 Eylül 1983, ss. 1, 11.

130 Council of Europe-Parliamentary Assembly, Situation in Turkey, Resolution 803, http://semanticpace.net/tools/pdf.aspx?doc=aHR0cDovL2Fzc2VtYmx5LmNvZS5pbnQvbncveG1sL1hSZWYvWDJILURXLWV4 dHIuYXNwP2ZpbGVpZD0xNjIxNCZsYW5nPUVO\&xsl=aHR0cDovL3NlbWFudGljcGFjZS5uZXQvWHNsdC9Q ZGYvWFJ1Zi1XRC1BVC1YTUwyUERGLnhzbA==\&xsltparams=ZmlsZWlkPTE2MjE0, (05.04.2020).

131 “Avrupa Konseyi’nde Olmasak da Var Olacağız”, Tercüman, 4 Ekim 1983, ss. 1, 10.

132 "Avrupa Konseyi Başkan Yardımcısı ile Danışma Meclisi Siyasi Komisyonu'nun Türkiye Raportörü Türkiye İçin Ne Dediler?", Milliyet, 2 Ekim 1983, s. 4.

133 "Yüksek Seçim Kurulu Kararı", T.C. Resmi Gazete, 14 Kasım 1983, ss. 13-59.
} 
Milletvekilleri, bu gelişmelerin Türk parlamenterlerin AKPM'de temsili sorununa çözüm getireceğine inanmışlardır. ${ }^{134}$ Genel anlamda Batı, Türk halkının istediği kişiyi seçerek gerçek demokrasiye geçme arzusunu gösterdiğine kanaat getirmiştir. ${ }^{135}$

24 Kasım 1983'te yapılan Avrupa Konseyi Bakanlar Komitesi toplantısında 6 Kasım seçimlerini olumlu bulan üyelerle birlikte eleştirenler de olmuştur. İlter Türkmen toplantıda yaptığı konuşmada seçimler ile demokratik parlamenter sürecin başladığını ve demokrasiye geçiş döneminin tamamlandığını ifade etmiştir. Konsey üyelerinden Yunanistan hariç tüm üyeler Türkiye'deki seçimleri olumlu bulmuş ve seçimlerin önemini vurgulamıştır. Ancak yine insan hakları ve özgürlükler konusunda Türkiye’ye karşı çekinceler devam etmiştir. ${ }^{136}$ Seçimler Türkiye'ye karşı yalnızca "kısmi bir ferahlama" getirmiştir. ${ }^{137}$ Bakanlar Komitesi toplantısı için Strasbourg'da bulunan İlter Türkmen, AKPM Dönem Başkanı Federal Alman Sosyal Demokrat Karl Ahrens ile özel bir görüşme yapmıştır. Görüşmede AKPM'nin 1984 Ocak ayı toplantısına katılacak olan Türk parlamenterlerin durumu ele alınmıştır. Ahrens Türk heyetin toplantıya katılmasını uygun bulurken sosyalist üyelerin buna olumlu bakmadığını belirtmiştir. Türkmen ise "adil" bir seçimle gelmiş parlamentonun Konsey'de temsil edilmemesinin çelişki yaratacağına dikkat çekmiştir. Aslında Türk parlamenterlerin Ocak ayındaki toplantıya girmelerini engelleyen bir tüzük maddesi bulunmadığı, ancak AKPM üyesinin diğer üyelerin yetki belgesine itiraz etme hakkı bulunduğu belirtilmiştir. Bu nedenle itiraz edilmesi durumunda Türk parlamenterlerin üyeliğinin reddi söz konusu olabilecekti. ${ }^{138}$

1984 yılına gelindiğinde Kenan Evren'in açıkladığı demokrasi takvimi tamamlanmış ve yönetim sivil iktidara teslim edilmiştir. 12 Eylül'den itibaren Türkiye'deki gelişmeleri yakından takip eden Avrupa Konseyi'nin artık nihai bir karar vermesi beklenmekteydi. Milliyet gazetesi Avrupa Konseyi'nin 1984 Ocak ayı toplantısı başlamadan önce Avrupa Konseyi üyeleri ile yaptığı anketin sonucunu paylaşmıştır. Ankette üyelere "bugün bir oylama olsa Türk parlamenterlerin Konsey'deki yerlerini almaları lehinde mi, aleyhinde mi oy verirsiniz?" sorusunu sormuştur. 12 Türk parlamenterin de oy kullandığı düşünüldüğünde 165 kişilik Konsey üyelerinin 57'sinin lehte, 78'inin aleyhte oy kullanacağı, 30'unun ise çekimser veya kararsız olduğu görüşmüştür. Eğer Türk parlamenterler oylamaya dahil edilmezse lehteki oy sayıs1 $45^{\prime} \mathrm{e}$ düşmüştür. Oylamaya katılacak üyelerin tam sayısının bilenememesi ve Steiner gibi kilit durumunda olan parlamenterlerin olumsuz oy kullanacaklarını beyan etmeleri de çıkan sonucun olumsuz olmasına neden olmuştur. Görüşülen üyelerin çoğunun Türkiye'nin lehinde oy kullanmak istemedikleri, ancak Türkiye'yi Avrupa'dan çıkarmaktan da endişe duydukları kaydedilmiştir. ${ }^{139}$ Avrupa Konseyi’nin Ocak ayı oturumu Türkiye ile Konsey arasında bir güç denemesi olarak değerlendirilmiştir. Konsey'den olumsuz karar çıkması Türkiye'nin Batı Avrupa ile ilişkilerini ciddi oranda sarsacak bir öneme sahipti. Olumsuz karar çıkması için de Konsey üyeleri çeşitli sendika ve konfederasyonlar tarafindan baskı altına alınmaktaydı. Türk parlamenterlerin Konsey çalışmalarına kabul edilmemesi bir anlamda seçimle gelen parlamentonun Türk halkını temsil etmediği ve demokratik olmadığı anlamı taşıyacaktı. Türkiye

\footnotetext{
134 “Ankara'da Bulunan Avrupa Konseyi Üyesi Yabancı Milletvekilleri: ‘Seçimler Dürüst ve Baskıdan Uzak Biçimde Yapıldı", Milliyet, 8 Kasim 1983, s. 5.

${ }_{135}$ Mehmet Ali Birand, "Seçimlere Dış Tepki: Türk Milleti Bizi Şaşırttı...", Milliyet, 11 Kasım 1983, s. 7.

136 Council of Europe, Minutes of The 73rd Session of The Committeeof Ninisters, 24 November 1983, https://rm.coe.int/native/09000016804d5e73, pg. 29-38, (10.09.2020).

137 "Avrupa Konseyi'nde Çekinceli Yumuşama”, Cumhuriyet, 28 Kasım 1983, ss. 1. 11.

138 "Avrupa Konseyi Türk Heyetinin Gelişini Ertele Eğiliminde", Cumhuriyet, 27 Kasım 1983, ss. 1, 6.

139 “Milliyet'in Anketi Sonuçlandı: Türkiye'nin Durumunu 'Kararsızlar’ Belirleyecek”, Milliyet, 29 Ocak 1983, s. 6.
} 
ise böyle bir durumda Bakanlar Komitesi'nden çekilerek Avrupa Konseyi'nden tamamen ayrılmayı düşünmekteydi. ${ }^{140}$

AKPM “Türkiye'deki durum ve Türk heyetinin kabul edilip edilmemesi” konusunu görüşmek üzere 3 O Ocak 1984'te Strasbourg'da toplantılara başlamıştır. ${ }^{141}$ Başlangıçta Türkiye'ye karş1 takınılan sert tutum toplantılar sırasında yumuşamaya başlamıştır. Gelişmeleri Strasbourg'da yakından takip eden Mehmet Ali Birand yumuşamanın nedenlerini üç madde ile sıralamıştır: Birinci olarak Türkiye'deki sosyalist ve sosyal demokratlar dahil olmak üzere Avrupa'daki Türk ve Batılı sosyalist grupların Konsey'e yolladıkları "Türkiye kopup giderse, zararlı olur" şeklindeki mesajlarının etkili olduğudur. İkinci olarak Batılı hükümetlerin Türkiye aleyhinde oylama yapılmaması için baskılarının artmasıdır. Üçüncü olarak da Türkiye aleyhinde oy çıkması durumunda Türkiye'nin Konsey'den ayrılma niyetinin ciddiyetinin anlaşılmasıdır. ${ }^{142}$ AKPM'nin 2 Şubat 1984 tarihli oturumunda uzlaşma sağlanamaması ve çevirmenlerin başlattıkları grev nedeniyle çalışmalar tatil edilmiş ve oylama Mayıs ayındaki toplantıya bırakılmıştır. Türkiye de Mayıs ayına kadar teknik olarak Konsey parlamentosunda kalmıştır. Konsey'de bulunan Türk parlamenterlerden Kamran İnan toplantının Türkiye açısından başarıyla tamamlandığını ifade etmiștir. ${ }^{143}$

Avrupa Konseyi Siyasi ve Tüzük Komisyonu üyelerinden oluşan alt komisyon 23-28 Nisan 1984 tarihleri arasında yaptıkları Türkiye gezisinden edindikleri izlenimleri Mayıs ayı toplantısı için Konsey'e sunmuştur. Steiner'in hazırladığı karar taslağında Türkiye'de demokrasiye dönme yolunda gözle görülür adımlar atıldığı vurgulanmakla birlikte sıkıyönetimin kaldırılması, af kanununun çıkarılması istenmiş, bazı davaların uzun sürmesinden duyulan rahatsızlık ifade edilmiş, savunma haklarına getirilen kısıtlamalar eleştirilmiş, Doğru Yol Partisi'ne karşı açılan davanın siyasi bir darbe niteliği taşıdığı, Yüksek Öğretim Kurumu'nun üniversitelerde eğitime gölge düşürdüğü belirtilmiştir. ${ }^{144}$ Türkiye için yapılacak oylamaya Konsey tarihinin en yüksek katılımı olmuş ve 161 üyenin 91'inin evet, 50'sinin hayır ve 10'nunun çekimser oy kullanması sonucunda Türk heyeti iki yıl aradan sonra AKPM'ye kabul edilmiştir. ${ }^{145}$ Ancak 10 Mayıs'ta kabul edilen kararda insan hakları ve demokrasi konusunda eksiklerin devam ettiği ve bunların yakından takip edileceği de vurgulanmıştır. ${ }^{146}$ Oylamalar sırasında Türk parlamenterlerden ANAP milletvekili İhsan Tombuş'un çekimser oy kullanması şaşkınlık yaratmıştır. İhsan Tombuş çekimser oy kullanarak kararın Türk parlamenterlerin oylarıyla değil diğer üyelerin oylarıyla kabul edildiğini göstermek istediğini belirtmiştir. Avrupa'daki insan hakları ve demokrasinin IMF'si olarak nitelendirilen Avrupa Konseyi ile ilişkilerin olumlu bir seyir kazanmasının Türkiye'nin diğer Batı Avrupa kuruluşlarıyla da ilişkilerinde olumlu bir etki yaratacağı beklenmiştir. ${ }^{147}$

\section{Sonuç}

12 Eylül Askeri Darbesi Türkiye'nin Avrupa Konseyi ile olan ilişkilerini olumsuz bir şekilde etkilemiştir. Ordu, gerçek demokrasiyi tesis etme söylemiyle mevcut demokrasiye darbe

\footnotetext{
140 “Avrupa Konseyi’nde Güç Denemesi”, Milliyet, 30 Ocak 1984, ss. 1, 7.

141 “Avrupa Konseyi’nde Türkiye Konusu Perşembeye Oylanacak”, Milliyet, 31 Ocak 1984, s. 7.

142 Mehmet Ali Birand, "Strasbourg'da Hava Neden Değişti?’, Milliyet, 1 Şubat 1984, s. 7.

143 “Avrupa Konseyi, Türkiye Konusunu Oylamadan Dağıldı”, Milliyet, 3 Şubat 1984, s. 7.

144 Council of Europe-Parliamentary Assembly, Situation in Turkey, Resolution 822, http://semanticpace.net/tools/pdf.aspx?doc=aHR0cDovL2Fzc2VtYmx5LmNvZS5pbnQvbncveG1sL1hSZWYvWDJILURXLWV4 dHIuYXNwP2ZpbGVpZD0xNjIzMyZsYW5nPUVO\&xsl=aHR0cDovL3NlbWFudGljcGFjZS5uZXQvWHNsdC9Q ZGYvWFJ1Zi1XRC1BVC1YTUwyUERGLnhzbA==\&xsltparams=ZmlsZWlkPTE2MjMz, (05.04.2020).

145 “Türk Heyetinin Yeniden Konsey’e Kabulü Onaylandı", Milliyet, 9 Mayıs 1984, s. 5.

${ }^{146}$ Council of Europe-Parliamentary Assembly, Situation in Turkey, Resolution 822

147 “Türk Heyetinin Yeniden Konsey’e Kabulü Onaylandı", Milliyet, 9 Mayıs 1984, s. 5.
} 
indirmiştir. Askeri rejim 12 Eylül'den itibaren demokratik parlamenter sistemin yeniden kurulacağını sık sık vurgulamış ve bunun için atılması gereken adımları atmıştır. Ancak demokrasi uğruna gerçekleştirilen uygulamalar demokrasiden uzak koşullar altında gerçekleştirilmiştir. Türkiye'deki gelişmeleri yakından takip eden Avrupa Konseyi, yılda en az iki kere toplanarak Türkiye'ye yönelik tavsiyelerini, kararlarını ve baskılarını sürdürmüş̧ür. Avrupa Konseyi darbenin yapıldığı ilk aylardan itibaren seçimlerin yapılması için sık sık uyarıda bulunmuş ve demokrasiye dönüş için tarih beklemiştir. Kenan Evren'in "Demokrasiye Avrupalı dostlarımız istediği için değil, Türk milletine en yaraşır bir idare şekli olduğu için geçiyoruz. Avrupalı dostlarımız bu konuda bizi rahat bıraksalardı, yapacaklarımızı belki de daha kısa zamanda yapabilecektik". ${ }^{48}$ ifadesi Türkiye'ye yönelik bask1 olduğunu açıça ortaya koymaktadır. Avrupa Konseyi, Türkiye için en büyük baskı aracı olarak "Konsey üyeliği" konusunu kullanmıştır. Ocak 1982 raporunda hatırlanacağı üzere Türk hükümetinin ve halkının Konsey'de kalma isteğinin, Konsey’e Türkiye'deki gelişmeleri etkileyebilme olanağı verdiği açıkça yer almıştır. Ancak hem Avrupa için Türkiye'nin stratejik önemi hem de Türkiye için Avrupalı olma düşüncesi, ilişkilerin kesilip atılmasına engel olmuştur. Avrupa Konseyi’nin Türkiye'nin demokratikleşme sürecine etkisine bakıldığında ise Kenan Evren'in Konsey'in beklentilerini göz önünde bulundurduğu da görülmüştür. Evren'in 7 Aralık 1981'de Türkiye'ye gelecek Konsey heyetinin ziyaretini erteleyerek 30 Aralık'ta önce demokrasi takvimini açıklaması bu düşünceyi desteklemektedir. Demokrasi takvimi kapsamında özellikle 1982 halkoylaması ve 1983 seçim süreçleri antidemokratik geçmesine rağmen Avrupa Konseyi'nin iki oylamayı da baskıdan uzak ve demokratik olarak değerlendirmesi şaşırtıcı bulunmuştur.

\section{Kaynakça}

\section{I.Resmi Yayınlar}

Volume 12

Danışma Meclisi Tutanak Dergisi, C. 10, 156'ncı Birleşim, 23 Eylül 1982.

Milli Güvenlik Konseyi Tutanak Dergisi

TBMM Tutanak Dergisi, C. 22, On altıncı Birleşim, 12.XII.1949.

\section{T.C Resmi Gazete}

\section{Gazeteler}

Cumhuriyet

Hürriyet

Milliyet

Tercüman

The Times

\section{Araştırma ve Tetkik Eserler}

ARMAOĞLU, Fahir, 20. Yüzyll Siyasi Tarihi (1914-1995), 23. Basım, Timaş Yayınları, İstanbul 2017.

ASLAN, Zehra, “Türk-Rus İlişkileri Ekseninde Türkiye'de İktidarların 'Sol' Algısı (19231960)", Karadeniz Araştırmaları, S. 51, Güz 2016, s. 171-190.

\footnotetext{
148 'Evren, Diyarbakır'da Siyasi Partiler Düzeni Hakkındaki Anayasa Hükümlerini Anlattı”, Tercüman, 28 Ekim 1982, ss. 1,11 .
} 
Avrupa Konseyi-Türkiye İlişkilerinin Türk Basınında Yansımaları (1980-1984)

“Avrupa Konseyi Statüsü”, Ankara Barosu Dergisi, Y11: 75, 2017/3, s. 585-596.

AYDIN, Mustafa, "1939-1945: Savaş Kaosunda Türkiye, Göreli Özerklik-2”, Türk Dış Politikası, Ed. Baskın Oran, C. I, 15. Basım, İletişim Yayınları, İstanbul 2009, s. 385-476.

AYDIN, Suavi -Yüksel Taşkın, 1960'dan Günümüze Türkiye Tarihi, 5. Basım, İletişim Yayınları, İstanbul 2017.

DAĞI, İhsan Duran, "Democratic Transition in Turkey, 1980-83: The Impact of European Diplomacy”, Middle Eastern Studies, 32/2, 1996, pg. 124-141.

DURSUN, Davut, 12 Eylül Darbesi Hatıralar Gözlemler Düşünceler, Şehir Yayınları, İstanbul 2005.

ESENER, Kaan, Avrupa Konseyi ve Türkiye, (Ankara Üniversitesi Sosyal Bilimler Enstitüsü Yayımlanmamış Yüksek Lisans Tezi), Ankara 2003.

EVREN, Kenan, Kenan Evren'in Anıları, C. 2, Milliyet Yayınları, İstanbul 1991.

EVREN, Kenan, Kenan Evren 'in Anılarl, C. 4, Milliyet Yayınları, İstanbul 1991.

GÖNLÜBOL, Mehmet -Haluk Ülman, "İkinci Dünya Savaşından Sonra Türk Dış Politikası (1945-1965):Genel Durum”, Olaylarla Türk Dış Politikası (1919-1995), 9. Basım, Siyasal Kitabevi, Ankara 1996, s. 191-334.

HALE, William, Türk Dış Politikası 1774-2000, Çev. Petek Demir, Mozaik Yayınları, İstanbul 2003.

,Türkiye'de Ordu ve Siyaset, Çev. Ahmet Fethi, Alfa Yayınları, İstanbul 2014.

KOÇAK, Cemil, Türkiye'de Milli Şef Dönemi (1938-1845), C. 2, 7. Basım, İletişim Yayınları, İstanbul 2017.

ÖNCÜ, Ali Servet-Erkan Cevizliler, “Avrupa Bütünleşmesi İçin Önemli Bir Adım: ‘Avrupa Konseyi’ ve Türkiye'nin Konseye Üyeliği Meselesi, Akademik Bakış, 7/13, 2013, s. 1544.

SARINAY, Yusuf, “Türkiye'nin NATO’ya Girişi”, Türkler Ansiklopedisi, C. 16, Yeni Türkiye Yayınlar1, Ankara 2002, s. 1707-1714.

ŞAHHÜSEYINOĞLU, H. Nedim, Dünden Bugüne Düşünceye ve Basına Sansür, 2. Basım, Ürün Yayınları, Ankara 2015.

UÇAROL, Rifat, Siyasi Tarih (1789-2014), 10. Basım, Der Yayınları, İstanbul 2015.

\section{Internet Kaynakları/ Avrupa Konseyi Parlamenter Meclisi ve Bakanlar Komitesi Tutanakları}

Council of Europe-Parliamentary Assembly, Situation in Turkey, Recommendation 904, http://semantic-

pace.net/tools/pdf.aspx?doc=aHR0cDovL2Fzc2VtYmx5LmNvZS5pbnQvbncveG1sL1h SZWYvWDJILURXLWV4dHIuYXNwP2ZpbGVpZD0xNDkzOCZsYW5nPUVO\&xsl= aHR0cDovL3NlbWFudGljcGFjZS5uZXQvWHNsdC9QZGYvWFJlZi1XRC1BVC1YT UwyUERGLnhzbA==\&xsltparams=ZmlsZWlkPTE0OTM4 (05.04.2020).

Council of Europe-Parliamentary Assembly, Situation in Turkey, Order 395, http://semanticpace.net/tools/pdf.aspx?doc=aHR0cDovL2Fzc2VtYmx5LmNvZS5pbnQvbncveG1sL1h SZWYvWDJILURXLWV4dHIuYXNwP2ZpbGVpZD0xMzYwMSZsYW5nPUVO\&xsl 
=aHR0cDovL3NlbWFudGljcGFjZS5uZXQvWHNsdC9QZGYvWFJ1Zi1XRC1BVC1Y

TUwyUERGLnhzbA==\&xsltparams=ZmlsZWlkPTEzNjAx, (05.04.2020).

Council of Europe-Parliamentary Assembly, Term of Office of The Turkish Parliamentary Delegation, Order 398 http://assembly.coe.int/nw/xml/XRef/Xref-XML2HTMLen.asp?fileid=13604\&lang=en, (04.05.2020).

Council of Europe-Parliamentary Assembly, Resolution 757, http://semanticpace.net/tools/pdf.aspx?doc=aHR0cDovL2Fzc2VtYmx5LmNvZS5pbnQvbncveG1sL1h SZWYvWDJILURXLWV4dHIuYXNwP2ZpbGVpZD0xNjE2OCZsYW5nPUVO\&xsl= aHR0cDovL3NlbWFudGljcGFjZS5uZXQvWHNsdC9QZGYvWFJIZi1XRC1BVC1YT UwyUERGLnhzbA==\&xsltparams=ZmlsZWlkPTE2MTY4, (05.04.2020).

Council of Europe-Parliamentary Assembly, Situation in Turkey, Order 406, http://semanticpace.net/tools/pdf.aspx?doc=aHR0cDovL2Fzc2VtYmx5LmNvZS5pbnQvbncveG1sL1h SZWYvWDJILURXLWV4dHIuYXNwP2ZpbGVpZD0xMzYxMiZsYW5nPUVO\&xsl= aHR0cDovL3NlbWFudGljcGFjZS5uZXQvWHNsdC9QZGYvWFJlZi1XRC1BVC1YT UwyUERGLnhzbA==\&xsltparams=ZmlsZWlkPTEzNjEy, Resolution 765, (04.05.2020).

Council of Europe-Parliamentary Assembly, Situation in Turkey, Resolution 765, http://semantic-

pace.net/tools/pdf.aspx?doc=aHR0cDovL2Fzc2VtYmx5LmNvZS5pbnQvbncveG1sL1h SZWYvWDJILURXLWV4dHIuYXNwP2ZpbGVpZD0xNjE3NiZsYW5nPUVO\&xsl=a HR0cDovL3NlbWFudGljcGFjZS5uZXQvWHNsdC9QZGYvWFJ1Zi1XRC1BVC1YTU wyUERGLnhzbA==\&xsltparams=ZmlsZWlkPTE2MTc2, (05.04.2020).

Volume 12

Council of Europe-Parliamentary Assembly, Situation in Turkey, Recommendation 936, http://semantic-

pace.net/tools/pdf.aspx?doc=aHR0cDovL2Fzc2VtYmx5LmNvZS5pbnQvbncveG1sL1h SZWYvWDJILURXLWV4dHIuYXNwP2ZpbGVpZD0xNDk3MCZsYW5nPUVO\&xsl $=a$ aHR0cDovL3NlbWFudGljcGFjZS5uZXQvWHNsdC9QZGYvWFJ1Zi1XRC1BVC1Y TUwyUERGLnhzbA==\&xsltparams=ZmlsZWlkPTE0OTcw, (05.04.2020).

Council of Europe-Parliamentary Assembly, Situation in Turkey, Resolution 786, http://semantic-

pace.net/tools/pdf.aspx?doc=aHR0cDovL2Fzc2VtYmx5LmNvZS5pbnQvbncveG1sL1h SZWYvWDJILURXLWV4dHIuYXNwP2ZpbGVpZD0xNjE5NyZsYW5nPUVO\&xsl=a HR0cDovL3NlbWFudGljcGFjZS5uZXQvWHNsdC9QZGYvWFJ1Zi1XRC1BVC1YTU wyUERGLnhzbA==\&xsltparams=ZmlsZWlkPTE2MTk3, (05.04.2020).

Council of Europe-Parliamentary Assembly, Situation in Turkey, Resolution 794, http://semantic-

pace.net/tools/pdf.aspx?doc=aHR0cDovL2Fzc2VtYmx5LmNvZS5pbnQvbncveG1sL1h SZWYvWDJILURXLWV4dHIuYXNwP2ZpbGVpZD0xNjIwNSZsYW5nPUVO\&xsl=a HR0cDovL3NlbWFudGljcGFjZS5uZXQvWHNsdC9QZGYvWFJ1Zi1XRC1BVC1YTU wyUERGLnhzbA==\&xsltparams=ZmlsZWlkPTE2MjA1, (05.04.2020).

Council of Europe-Parliamentary Assembly, Situation in Turkey, Resolution 803, http://semantic-

pace.net/tools/pdf.aspx?doc=aHR0cDovL2Fzc2VtYmx5LmNvZS5pbnQvbncveG1sL1h SZWYvWDJILURXLWV4dHIuYXNwP2ZpbGVpZD0xNjIxNCZsYW5nPUVO\&xsl=a HR0cDovL3NlbWFudGljcGFjZS5uZXQvWHNsdC9QZGYvWFJ1Zi1XRC1BVC1YTU wyUERGLnhzbA==\&xsltparams=ZmlsZWlkPTE2MjE0, (05.04.2020). 
Council of Europe-Parliamentary Assembly, Situation in Turkey, Resolution 822, http://semantic-

pace.net/tools/pdf.aspx?doc=aHR0cDovL2Fzc2VtYmx5LmNvZS5pbnQvbncveG1sL1h SZWYvWDJILURXLWV4dHIuYXNwP2ZpbGVpZD0xNjIzMyZsYW5nPUVO\&xsl=a HR0cDovL3NlbWFudGljcGFjZS5uZXQvWHNsdC9QZGYvWFJIZi1XRC1BVC1YTU wyUERGLnhzbA==\&xsltparams=ZmlsZWlkPTE2MjMz, (05.04.2020).

Council of Europe, Minutes of The 67th Session of The Committeeof Ninisters, 16 October 1980, https://rm.coe.int/native/09000016804d64d3, pg. 25-27, (10.09.2020).

Council of Europe, Minutes of The 71st Session of The Committeeof Ninisters, 10 November 1982, https://rm.coe.int/native/09000016804d662a, pg. 26-32, (10.09.2020).

Council of Europe, Minutes of The 73rd Session of The Committeeof Ninisters, 24 November 1983, https://rm.coe.int/native/09000016804d5e73, pg. 29-38, (10.09.2020). 